\title{
RUPTURE PATTERNS AND PRESHOCKS OF LARGE EARTHQUAKES IN THE SOUTHERN SAN JACINTO FAULT ZONE
}

\author{
By Chris Sanders, Harold Magistrale, and Hiroo Kanamori
}

\begin{abstract}
We relocated the large 1937, 1942, and 1954 earthquakes in the San Jacinto fault zone. The epicenters of the main shocks, aftershocks, and some preshocks were determined using empirical station corrections from recent small events in the study areas. The $1937\left(M_{L} 5.9\right)$ earthquake has an epicenter between the surface traces of the San Jacinto and Buck Ridge faults, and aftershocks suggest about $7 \mathrm{~km}$ of rupture predominantly to the northwest. A significant increase in small earthquake activity occurred about $1 \frac{1}{2}$ yr before this event. The $1954\left(M_{L}\right.$ 6.2) earthquake is located at the southeast end of the mapped trace of the San Jacinto fault, and aftershocks suggest about $15 \mathrm{~km}$ of rupture further southeast into an area of folded young sediments with no surface fault trace. This event was preceded by a cluster of small earthquakes which occurred within an 8-hr period 10 weeks before the main event and in the eventual rupture zone. The $1942\left(M_{L} 6.3\right)$ earthquake is located southwest of the southeast end of the Coyote Creek fault. Large aftershocks of this event are spread over a 15 by $18 \mathrm{~km}$ area southwest of the Coyote Creek fault and are not associated with any one fault. The relation of the 1942 event to the San Jacinto fault zone is not simple.
\end{abstract}

\section{INTRODUCTION}

The San Jacinto fault zone is a major right-slip fault zone in southern California. Historically, it is the most seismically active fault zone in California. To improve our understanding of the seismic history of this fault zone, we relocated the large $1937\left(M_{L} 5.9\right), 1942\left(M_{L} 6.3\right)$, and $1954\left(M_{L} 6.2\right)$ earthquakes and aftershocks which were caused by rupture of segments of the San Jacinto and Coyote Creek faults and a fault southwest of the Coyote Creek fault. Together with the $1968\left(M_{L} 6.8\right)$ Borrego Mountain earthquake, these events represent the greatest stress release along the southern half of the San Jacinto fault zone since at least the late 1890's, and their rupture zones help define those segments of the fault zone which have ruptured historically and those segments which have not.

Originally, the large earthquakes were located by graphical techniques using $S-P$ times from distant ( $\Delta=100$ to $500 \mathrm{~km}$ ) unclipped stations, and the numerous aftershocks were given the same epicenters as the associated main shocks (Hileman et al., 1973). Other researchers have attempted relocations of some of the main shocks. The 1937 earthquake was originally located by Wood (1937) and relocated by Gutenberg (1943), Richter (1958), Hileman et al. (1973), Hanks et al. (1975), and Sanders and Kanamori (1984). The 1942 and 1954 earthquakes were originally located by Richter (1958) and also relocated by Hanks et al. (1975). Wood, Gutenberg, and Richter used main shock $S$ - $P$ times recorded at some of the seven or more southern California seismograph stations in operation at the time and then graphically located the events using empirical $S-P$ versus $\Delta$ curves. Hanks et al. also graphically located the main shocks but used the average aftershock $S-P$ times to approximate the main shock times. This increased the number of $S-P$ readings since some of the main shock $S$-wave arrival times are unreadable. Hileman et al. located the 1937 main shock using available $P$ - and $S$-wave arrival times, a leastsquares computer routine, and a single layer crustal velocity model. Sanders and Kanamori located the 1937 main shock using a modern computer location program, 
a multi-layer crustal velocity model, $P$-wave arrival times at six southern California stations ( $\Delta=100$ to $400 \mathrm{~km})$, and $P$ - and $S$-wave arrivals at one station $(\Delta=100$ $\mathrm{km})$. No station corrections were used for this later location, however.

Since very few seismograms are available for locating these large earthquakes, and since these are from large distances and limited azimuths, all of the previous locations suffer from large uncertainties $( \pm 10$ to $15 \mathrm{~km})$. In order to minimize the effects of the sparse, heterogeneous data set, we include data on the lateral variations in the regional velocity structure. This data is introduced into the earthquake

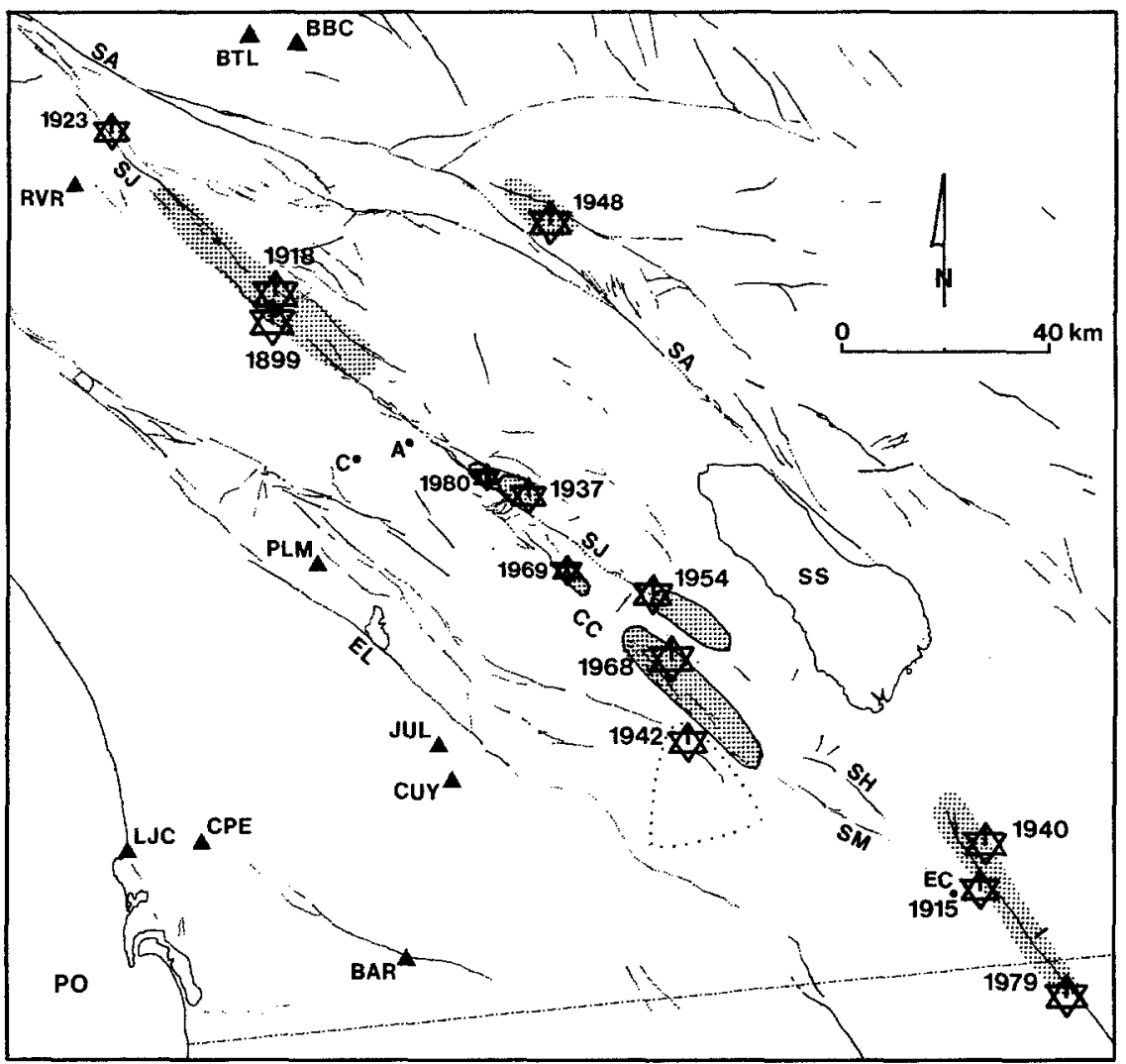

Fig. 1. Map of historic large earthquake rupture zones on the San Jacinto, southern San Andreas, and Imperial faults in southern California. The main shock epicenters are indicated by stars and the aftershock zones of the $1937\left(M_{L} 5.9\right), 1940\left(M_{S} 7.1\right), 1948\left(M_{L} 6 \frac{1}{2}\right), 1954\left(M_{L} 6.2\right), 1968\left(M_{L} 6.8\right), 1969$ $\left(M_{L} 5.8\right)$, and $1980\left(M_{L} 5.5\right)$ events are shaded. The principal $1942\left(M_{L} 6.3\right)$ earthquake aftershocks lie within the dotted outline. The 1923 earthquake was $M_{L} 6 \frac{1}{4}$ and both 1915 main shocks were $M_{L} 6.3$. The combined rupture zone of the 1899 and 1918 San Jacinto earthquakes is approximated based on magnitude versus fault length relations. A, Anza; C, Cahuilla; CC, Coyote Creek fault; EC, El Centro; EL, Elsinore fault; I, Imperial fault; PO, Pacific Ocean; SA, San Andreas fault; SH, Superstition Hills fault; SJ, San Jacinto fault; SM, Superstition Mountain fault; and SS, Salton Sea. Triangles mark seismograph stations used in this study.

location procedure in the form of empirical station corrections as explained in the next section. The resulting epicentral locations hopefully suffer less from the sparse travel-time data set. We feel that these more precise epicentral locations for the main shocks plus the first locations of the aftershocks will help clarify the recent seismic history of the San Jacinto fault zone.

\section{TECHNIQUE}

We precisely relocated the 1937, 1942, and 1954 main shocks and aftershocks and the 1937 and 1954 preshocks using a simple technique. $P$ - and $S$-wave arrival times 
from some or all of the California Institute of Technology seismograph stations located at Riverside (RVR), La Jolla (LJC), Palomar (PLM), Barret Dam (BAR), Big Bear (BBC), and Cuyamaca Reservoir (CUY) are used to find the epicentral locations (Figure 1). Usually only two stations separated by about $75^{\circ}$ azimuth are available for use in our relocations (since we try to use predominantly $P_{g}$ and $S_{g}$ arrivals), so very accurate delay values are needed to account for the deviation between the observed travel time through the real earth and the travel time calculated through the idealized crustal velocity model used in the earthquake location program (unpublished program, Johnson, 1979). The delay values vary from station to station and also somewhat from source area to source area. Thus,

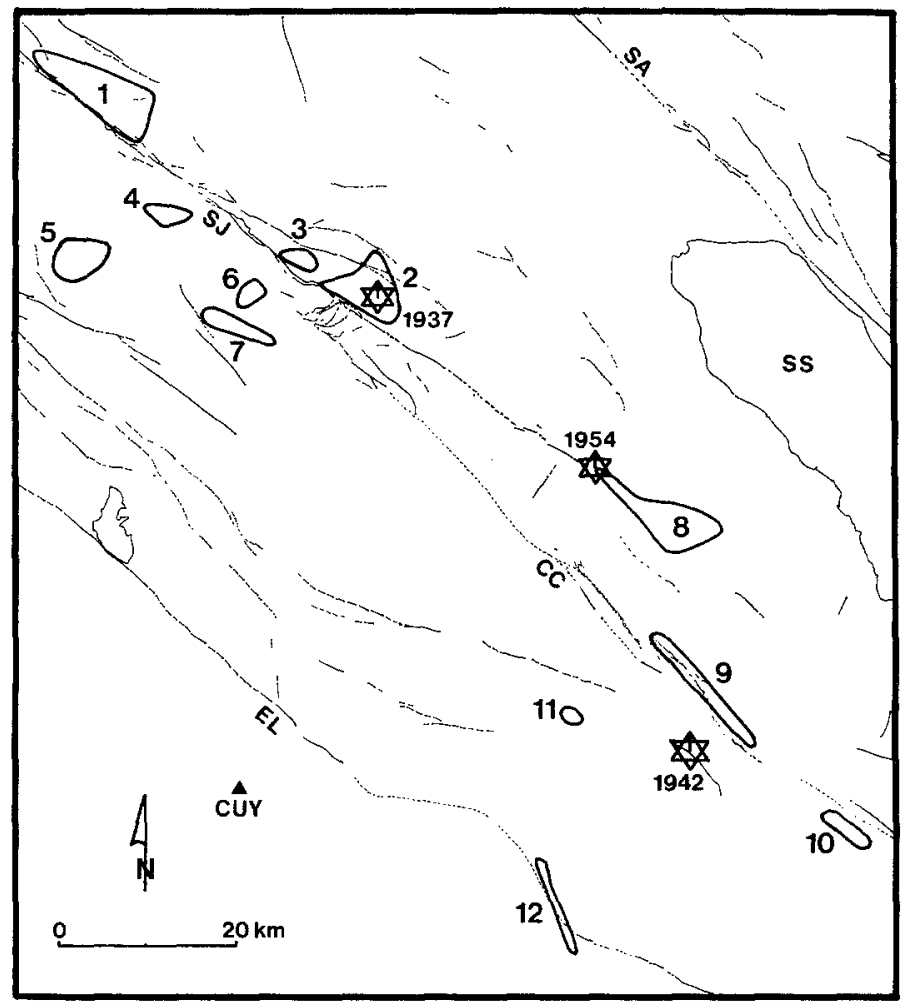

FIG. 2. Map of areas along the southern San Jacinto fault zone for which travel-time delays have been determined. The numbers are referred to in the text and in Table 1.

we determined accurate delay values to each station for many different subareas in the general region of the southern San Jacinto fault zone (Figure 2, Tables 1 and 6). These values were obtained by averaging the results (observed travel time minus calculated travel time) at the above named stations from many recent (1977 to 1985) small earthquakes. These small earthquakes were relocated using the dense USGS-CIT southern California seismograph network now in operation and stations within 60 to $80 \mathrm{~km}$ of the epicenter [to minimize the effect of uncertainties in the velocity model (Pechmann, 1983)]. We used a crustal $P$-wave velocity model characteristic of the Peninsular Ranges of southern California (Table 2) (Kanamori and Hadley, 1975; Hadley and Kanamori, 1977), and the $S$-wave velocities were calculated with $V_{P} / V_{S}=1.78$. The residuals at a particular station from well-located earthquakes in a given small area are consistent, and we are able to obtain average 
TABIE 1. Recent Earthquake Residuals Near the 1937 and 1054 Earthquakes

\begin{tabular}{|c|c|c|c|c|c|c|c|c|c|c|c|c|c|c|}
\hline \multirow[b]{2}{*}{$\#$} & \multirow[b]{2}{*}{ YR MO DA } & \multirow[b]{2}{*}{ HRMN } & \multirow[b]{2}{*}{ LAT } & \multirow[b]{2}{*}{ LON } & \multirow[b]{2}{*}{ D } & \multirow[b]{2}{*}{$\mathrm{M}_{\mathrm{L}}$} & \multicolumn{2}{|c|}{ RVR } & \multicolumn{2}{|c|}{ LJC (CPE) } & \multicolumn{2}{|c|}{ BAR } & \multicolumn{2}{|c|}{ PLM } \\
\hline & & & & & & & $\mathrm{P}$ & $\mathrm{S}$ & $\mathrm{P}$ & $\mathbf{S}$ & $\mathbf{P}$ & $\mathbf{S}$ & $\mathbf{P}$ & $\mathrm{S}$ \\
\hline \multirow{4}{*}{1} & 770702 & 0122 & $33^{\circ} 37.10^{\prime}$ & $110^{\circ} 42.87^{\prime}$ & 14.1 & 3.0 & -0.18 & -1.12 & -0.07 & & & & 0.58 & \\
\hline & 780803 & 0430 & $33^{\circ} 40.44^{\prime}$ & $110^{\circ} 41.10^{\prime}$ & 15.2 & 3.5 & & & -0.55 & & -0.25 & & 0.14 & \\
\hline & 790822 & 0201 & $33^{\circ} 42.39^{\prime}$ & $116^{0} 50.07^{\prime}$ & 15.5 & 4.0 & -0.15 & & -0.33 & & -0.02 & & 0.32 & \\
\hline & & & & & & & $\overline{-0.17}$ & $\overline{-1.12}$ & $\overline{-0.32}$ & & $\overline{-0.14}$ & & $\overline{+0.34}$ & \\
\hline \multirow{21}{*}{2} & 760714 & $201 \theta$ & $33^{\circ} 28.40^{\prime}$ & $116^{\circ} 28.86^{\prime}$ & 0.0 & 2.7 & & -1.31 & -0.40 & -1.26 & & & 0.15 & 0.22 \\
\hline & 760717 & 1121 & $33^{\circ} 28.45^{\prime}$ & $110^{\circ} 28.54^{*}$ & 8.6 & 2.8 & & -1.56 & & -1.32 & & & 0.13 & \\
\hline & 770208 & 1239 & $33^{\circ} 28.77^{\prime}$ & $116^{\circ} 27.35^{\circ}$ & 13.3 & 2.5 & & & -0.27 & -1.44 & & & 0.10 & \\
\hline & 771022 & 0933 & $33^{\circ} 27.80^{\prime}$ & $116^{\circ} 24.27$ & 9.3 & 2.3 & & & -0.42 & -1.53 & & & 0.05 & \\
\hline & 771025 & 1531 & $33^{\circ} 28.92$ & $116^{\circ} 26.03^{\prime}$ & 12.8 & 2.7 & & & -0.47 & -1.88 & & & 0.05 & \\
\hline & 771128 & 1857 & $33^{\circ} 26.86^{\prime}$ & $118^{\circ} 24.34^{\prime}$ & 11.6 & 3.1 & & -1.14 & -0.54 & & & & 0.16 & \\
\hline & 780301 & 1141 & $33^{\circ} 27.82^{\prime}$ & $110^{0} 24.05^{\prime}$ & 9.8 & 2.1 & & & -0.14 & & & & & \\
\hline & 780512 & 1548 & $33^{\circ} 20.55^{\prime}$ & $110^{\circ} 28.10^{\prime}$ & 12.8 & 2.8 & & & -0.28 & -1.62 & $-0.1 \theta$ & -1.47 & 0.12 & 0.27 \\
\hline & 781008 & 0852 & $33^{\circ} 30.53^{\prime}$ & $110^{\circ} 25.62^{\prime}$ & 9.6 & 2.3 & & & -0.33 & -1.84 & & & 0.18 & \\
\hline & 781201 & 0229 & $33^{\circ} 28.93^{\prime}$ & $116^{\circ} 28.91^{\prime}$ & 14.0 & 3.0 & & & -0.31 & -1.62 & -0.19 & -1.20 & 0.14 & \\
\hline & 780212 & 0448 & $33^{\circ} 27.60^{\prime}$ & $110^{\circ} 25.71^{\prime}$ & 5.5 & 4.2 & -0.24 & & -0.38 & & -0.22 & & 0.20 & \\
\hline & $7 \theta 0212$ & 0455 & $33^{\circ} 27.4 \theta^{\prime}$ & $116^{\circ} 25.67^{\prime}$ & 4.6 & 3.2 & & & -0.37 & & -0.14 & & 0.19 & 0.18 \\
\hline & 790212 & 0515 & $33^{\circ} 27.51^{\prime}$ & $116^{\circ} 25.87^{\prime}$ & 5.0 & 3.0 & & & -0.38 & & -0.22 & & 0.20 & \\
\hline & 790812 & 1258 & $33^{\circ} 29.99^{\circ}$ & $116^{\circ} 25.58^{\prime}$ & 10.0 & 2.6 & & & -0.33 & -1.27 & & -1.13 & 0.14 & 0.21 \\
\hline & 790910 & 0855 & $38^{\circ} 28.08^{\prime}$ & $110^{\circ} 29.58^{\prime}$ & 7.5 & 3.0 & -0.16 & & -0.24 & -1.24 & -0.26 & -1.51 & 0.25 & \\
\hline & & & & & & & -0.20 & $\overline{-1.34}$ & $\overline{-0.33}$ & $\overline{-1.45}$ & $\overline{-0.20}$ & $\overline{-1.35}$ & $\overline{+0.15}$ & $\mp 0.22$ \\
\hline & 790702 & 1151 & $33^{0} 29.98^{\prime}$ & $110^{\circ} 20.96^{\prime}$ & 13.7 & 3.7 & -0.25 & & -0.33 & & -0.20 & & 0.11 & \\
\hline & 700702 & 1242 & $33^{\circ} 30.55^{\prime}$ & $110^{\circ} 30.44^{\prime}$ & 12.6 & 3.6 & -0.28 & -1.41 & -0.33 & -1.64 & -0.21 & -1.42 & 0.18 & \\
\hline & 800225 & 1053 & $33^{\circ} 30.44^{\prime}$ & $110^{\circ} 30.87^{\prime}$ & 12.8 & 5.5 & -0.28 & & -0.47 & & -0.32 & & 0.15 & \\
\hline & 800225 & 1141 & $33^{\circ} 30.64^{\prime}$ & $110^{\circ} 31.42^{\prime}$ & 10.5 & 2.7 & -0.31 & -1.37 & -0.59 & & -0.45 & -1.82 & 0.13 & 0.24 \\
\hline & 800225 & 1147 & $33^{\circ} 30.53^{\prime}$ & $110^{\circ} 31.37^{\prime}$ & 11.5 & 2.4 & & -1.31 & -0.26 & -1.82 & -0.21 & -1.61 & 0.21 & 0.25 \\
\hline 3 & 800225 & 1149 & $33^{\circ} 30.4 \theta^{\prime}$ & $118^{\circ} 32.20^{\prime}$ & 11.5 & 2.5 & & & -0.37 & -1.74 & -0.32 & -1.68 & 0.21 & 0.31 \\
\hline & 800225 & 1203 & $33^{\circ} 30.58^{\prime}$ & $110^{\circ} 31.11^{\prime}$ & 10.8 & 2.7 & & & -0.46 & -1.87 & -0.33 & -1.68 & 0.15 & \\
\hline & 800225 & 1207 & $33^{\circ} 30.42^{\prime}$ & $116^{\circ} 31.29^{\circ}$ & 10.0 & 2.1 & & & -0.43 & -1.80 & & & 0,11 & \\
\hline & 800225 & 1300 & $33^{\circ} 30.33^{\prime}$ & $110^{\circ} 31.24^{\prime}$ & 11.2 & 2.1 & & & -0.24 & -1.78 & -0.26 & -1.65 & 0.22 & 0.32 \\
\hline & 800225 & 1451 & $33^{\circ} 30.49^{\prime}$ & $116^{\circ} 31.75^{\prime}$ & 11.2 & 3.3 & -0.12 & -1.10 & -0.38 & -1.70 & -0.32 & -1.71 & 0.28 & \\
\hline & 800225 & 1007 & $33^{\circ} 30.26^{\circ}$ & $116^{\circ} 31.51^{\prime}$ & 10.4 & 2.4 & & & -0.44 & -1.78 & -0.33 & -1.58 & 0.16 & \\
\hline & 810430 & 2009 & $33^{\circ} 30.70^{\prime}$ & $116^{\circ} 30.37^{\prime}$ & 18.8 & 3.2 & -0.03 & -1.24 & & & -0.20 & -1.38 & 0.15 & \\
\hline & & & & & & & $\overline{-0.21}$ & -1.28 & $\overline{-0.38}$ & $\overline{-1.75}$ & -0.29 & $\overline{-1.61}$ & $\overline{+0.17}$ & $\overline{+0.28}$ \\
\hline & 800907 & 0320 & $33^{\circ} 32.28^{\prime}$ & $116^{\circ} 40.54^{\prime}$ & 8.4 & 2.7 & -0.23 & & & & -0.22 & & 0.30 & 0.46 \\
\hline 4 & 810718 & 1248 & $33^{\circ} 33.35^{\prime}$ & $116^{\circ} 40.73^{\prime}$ & 11.0 & $2 . \theta$ & -0.24 & & & & -0.25 & & 0.24 & \\
\hline & 820615 & 2349 & $33^{0} 33.16^{\prime}$ & $110^{\circ} 40.51^{\prime}$ & 11.4 & 4.5 & -0.27 & & & & -0.36 & & 0.22 & \\
\hline & & & & & & & $\overline{-0.25}$ & & & & -0.28 & & $\overline{+0.25}$ & $+0.4 \theta$ \\
\hline & 780428 & 1440 & $33^{\circ} 31.64^{\prime}$ & $110^{\circ} 44.43^{\prime}$ & 5.6 & 2.3 & -0.04 & & -0.51 & -1.47 & $-0.2 \theta$ & & 0.04 & \\
\hline & $7806 \quad 14$ & 1044 & $33^{\circ} 28.83^{\prime}$ & $116^{\circ} 48.24^{\prime}$ & 13.0 & 3.0 & -0.18 & -1.05 & -0.39 & -1.08 & -0.22 & -1.21 & & \\
\hline & 790915 & 1101 & $33^{\circ} 31.50^{\prime}$ & $110^{\circ} 47.34^{\prime}$ & 5.0 & 2.1 & & & -0.49 & & -0.30 & & 0.12 & \\
\hline & 810201 & 1827 & $33^{\circ} 30.20^{\prime}$ & $116^{\circ} 40.12^{\prime}$ & 4.4 & 3.4 & -0.03 & & & & -0.20 & & 0.08 & \\
\hline & 810309 & 0336 & $33^{\circ} 30.48^{\prime}$ & $110^{\circ} 46.20^{\prime}$ & 6.0 & 2.7 & -0.08 & & & & & & & \\
\hline & 810312 & 1501 & $33^{\circ} 29.77^{\prime}$ & $110^{\circ} 48.78^{\prime}$ & 5.8 & 2.8 & -0.00 & -0.53 & & & -0.21 & -1.07 & 0.05 & \\
\hline & 810402 & 0343 & $33^{\circ} 30.22^{\prime}$ & $116^{\circ} 40.06^{\prime}$ & 4.0 & 2.3 & -0.01 & & & & & & 0.08 & \\
\hline & 810020 & 1948 & $33^{\circ} 30.73^{\prime}$ & $110^{\circ} 46.76^{\prime}$ & 2.4 & 2.8 & -0.14 & & & & -0.34 & & 0.18 & \\
\hline & 810701 & 0825 & $33^{\circ} 30.48^{\prime}$ & $110^{\circ} 48.03^{\prime}$ & 2.4 & 2.5 & -0.11 & & & & & & 0.18 & \\
\hline 5 & 810725 & 0824 & $33^{\circ} 29.13^{\prime}$ & $110^{\circ} 48.81^{\prime}$ & 1.5 & 3.1 & -0.07 & & & & -0.23 & & & \\
\hline & 810808 & 0218 & $33^{\circ} 28.49^{\prime}$ & $116^{\circ} 46.53^{\prime}$ & 2.2 & 2.7 & -0.07 & & & & -0.28 & & & \\
\hline & 810813 & 0509 & $33^{\circ} 28.06^{\prime}$ & $110^{\circ} 48.12^{\prime}$ & 4.8 & 2.5 & -0.19 & & & & & & 0.18 & \\
\hline & 811015 & 1441 & $33^{\circ} 32.15^{*}$ & $1.16^{\circ} 47.60^{\circ}$ & 4.5 & 2.2 & -0.03 & & & & -0.31 & & 0.04 & 0.27 \\
\hline & 811021 & 0537 & $33^{\circ} 30.28$ & $110^{\circ} 40.00^{\prime}$ & 4.6 & 3.1 & -0.10 & -0.80 & & & -0.32 & & 0.10 & \\
\hline & 811031 & 1851 & $33^{\circ} 28.54^{\prime}$ & $110^{\circ} 46.15^{\prime}$ & 5.0 & 2.7 & -0.03 & -0.60 & & & -0.26 & & & \\
\hline & 821022 & 1053 & $33^{\circ} 29.96^{\prime \prime}$ & $116^{\circ} 45.67^{\circ}$ & 7.0 & 2.4 & -0.30 & -0.87 & & & -0.45 & -1.36 & 0.12 & \\
\hline & 840325 & 0147 & $83^{\circ} 29.68^{\prime}$ & $110^{\circ} 48.01$ & 4.3 & 2.4 & -0.10 & & -0.58 & & -0.40 & & 0.18 & \\
\hline & 840818 & 0712 & $33^{\circ} 30.00^{\prime}$ & $110^{\circ} 47.55^{\prime}$ & 4.8 & 3.0 & & & $-0.5 \theta$ & & & & & \\
\hline & & & & & & & -0.09 & -0.78 & $\overline{-0.51}$ & $\overline{-1 . \overline{27}}$ & $\overline{-0.29}$ & -1.21 & $\overline{+0.11}$ & +0.27 \\
\hline
\end{tabular}

residual values for many areas along the San Jacinto fault. These average residual values become the delay values we use in relocating the older events.

Since the seismograph stations LJC, CUY, and BBC are no longer in operation, we use the nearby modern stations CPE, JUL, and BTL for determining station delays for the old stations. The relative locations are shown in Figure 1; CPE is 14 
RUPTURE PATTERNS/PRESHOCKS IN THE SAN JACINTO FAULT ZONE 1191

\begin{tabular}{|c|c|c|c|c|c|c|c|c|c|c|c|c|c|c|}
\hline \multirow[b]{2}{*}{$\#$} & \multirow[b]{2}{*}{ YR MO DA } & \multirow[b]{2}{*}{$\mathrm{HRMN}$} & \multirow[b]{2}{*}{ LAT } & \multirow[b]{2}{*}{ LON } & \multirow[b]{2}{*}{$\mathrm{D}$} & \multirow[b]{2}{*}{$M_{L}$} & \multicolumn{2}{|c|}{ RVR } & \multicolumn{2}{|c|}{ LNC (CPE) } & \multicolumn{2}{|c|}{$\mathrm{BAR}$} & \multicolumn{2}{|c|}{ PLA } \\
\hline & & & & & & & $\mathbf{P}$ & $\mathbf{S}$ & $\mathrm{P}$ & $S$ & $\mathrm{P}$ & $\mathrm{S}$ & $\mathrm{P}$ & $\mathrm{S}$ \\
\hline \multirow{6}{*}{6} & 780703 & 0834 & $33^{\circ} 27.03^{\prime}$ & $110^{\circ} 35.80^{\prime}$ & 8.6 & 2.9 & & & -0.35 & & -0.33 & -1.53 & 0.18 & \\
\hline & 781028 & 1014 & $33^{\circ} 28.1 \theta^{\circ}$ & $116^{\circ} 34.22^{\prime}$ & 11.0 & 2.5 & & & & -1.68 & -0.33 & -1.45 & 0.18 & 0.28 \\
\hline & 790802 & 1304 & $33^{\circ} 29.21^{\prime}$ & $110^{\circ} 34.10^{\prime}$ & 5.3 & 2.7 & -0.17 & & -0.44 & -1.51 & -0.37 & -1.52 & 0.15 & 0.12 \\
\hline & 800310 & 2332 & $33^{\circ} 28.27^{\prime}$ & $110^{\circ} 34.43^{\prime}$ & 10.0 & 3.0 & -0.24 & -1.43 & -0.49 & -1.72 & -0.39 & & 0.14 & 0.21 \\
\hline & 811230 & 0138 & $33^{\circ} 28.11^{\prime}$ & $116^{\circ} 33.7 \theta^{\prime}$ & 11.0 & 2.6 & -0.31 & & & & & & 0.11 & \\
\hline & & & & & & & $\overline{-0.24}$ & $\overline{-1.43}$ & $\overline{-0.43}$ & $\overline{-1.84}$ & $\overline{-0.38}$ & $\overline{-1.50}$ & $\overline{+0.15}$ & $\overline{+0.18}$ \\
\hline \multirow{6}{*}{7} & 790422 & 1852 & $33^{\circ} 25.63^{\prime}$ & $116^{\circ} 32.82^{\prime}$ & 12.0 & 3.3 & & -1.54 & -0.35 & -1.52 & -0.34 & -1.46 & $0.1 \theta$ & \\
\hline & 780801 & 0831 & $33^{\circ} 26.57^{\prime}$ & $110^{\circ} 37.87^{\prime}$ & 11.4 & 2.8 & 0.23 & & -0.08 & & -0.08 & & 0.38 & 0.40 \\
\hline & 790810 & 0220 & $33^{\circ} 28.87^{\prime}$ & $110^{\circ} 37.94^{\prime}$ & 8.2 & 3.0 & 0.27 & & -0.14 & -1.20 & -0.13 & & 0.47 & \\
\hline & $7 \theta 0819$ & 2255 & $33^{\circ} 27.03^{\prime}$ & $110^{\circ} 37.75$ & 8.2 & 2.8 & 0.17 & -3.44 & -0.25 & -1.44 & -0.23 & & 0.38 & \\
\hline & 790825 & 1340 & $33^{\circ} 27.30^{\prime}$ & $116^{\circ} 37.28^{\prime}$ & 7.4 & 2.3 & & & -0.49 & & -0.38 & & 0.18 & 0.50 \\
\hline & & & & & & & $\mp+0.22$ & $\overline{-1.4 \theta}$ & $\overline{-0.28}$ & $\overrightarrow{-1.39}$ & $\overline{-0.23}$ & -1.48 & $\overline{+0.32}$ & +0.45 \\
\hline \multirow{16}{*}{8} & 781109 & 2300 & $33^{\circ} 13.98^{\prime}$ & $116^{\circ} 04.46^{\circ}$ & 6.0 & 3.1 & & & -0.19 & -1.28 & -0.23 & -1.29 & 0.22 & \\
\hline & 800213 & 0031 & $33^{\circ} 18.09^{\prime \prime}$ & $116^{\circ} 09.90^{\prime}$ & 8.7 & 3.2 & & & -0.27 & & -0.36 & & 0.21 & \\
\hline & 810023 & 0130 & $33^{\circ} 14.27^{\prime}$ & $110^{\circ} 05.32^{\prime}$ & 10.5 & 2.1 & & & & & -0.17 & -1.09 & 0.54 & -0.14 \\
\hline & 810913 & 155.3 & $33^{\circ} 13.00^{\circ}$ & $116^{\circ} 04.84^{\prime}$ & 10.1 & 2.7 & & & & & -0.06 & -0.88 & 0.20 & \\
\hline & 810921 & 1521 & $33^{\circ} 14.15^{\circ}$ & $116^{\circ} 05.35^{\prime}$ & 10.0 & 2.0 & & & & & -0.13 & -1.38 & 0.23 & -0.14 \\
\hline & 810822 & 1011 & $33^{\circ} 14.13^{\prime}$ & $116^{\circ} 04.94^{\prime}$ & 8.0 & 2.1 & & & & & -0.06 & & 0.24 & \\
\hline & 811017 & 1847 & $33^{\circ} 14.41^{\prime}$ & $116^{\circ} 0-1.16^{\prime}$ & 4.9 & 3.8 & -1.21 & -1.31 & & & -0.30 & & 0.29 & \\
\hline & 811017 & 1853 & $33^{\circ} 14.29^{\prime}$ & $110^{\circ} 03.58^{\prime}$ & 8.7 & 2.4 & & & & & -0.07 & -1.33 & 0.38 & \\
\hline & 811017 & 1854 & $33^{\circ} 14.47^{\prime}$ & $110^{\circ} 03.81^{\prime}$ & 7.0 & 3.2 & & & & & -0.10 & -1.38 & 0.35 & \\
\hline & 811205 & 1558 & $33^{\circ} 13.98^{\prime}$ & $110^{\circ} 05.20^{\prime}$ & 9.7 & 2.2 & & & & & & & 0.31 & \\
\hline & 820125 & 2347 & $33^{\circ} 14.27^{\circ}$ & $110^{\circ} 05.32^{\prime}$ & 10.5 & 3.1 & & -1.28 & & & -0.21 & & 0.30 & -0.08 \\
\hline & 820007 & 0400 & $33^{\circ} 14.10^{\prime}$ & $110^{\circ} 05.66^{\prime}$ & 8.3 & 2.2 & & & & & -0.13 & -1.28 & 0.28 & -0.03 \\
\hline & 820015 & 1803 & $33^{\circ} 14.51^{\prime}$ & $116^{\circ} 01.17^{\prime}$ & 10.8 & 2.8 & & & & & -0.06 & -1.10 & 0.57 & \\
\hline & $8212 \quad 12$ & 1409 & $33^{\circ} 15.92^{\prime}$ & $110^{\circ} 08.70^{\prime \prime}$ & 10.4 & 2.5 & & & & & -0.10 & -1.48 & 0.02 & 0.12 \\
\hline & 841007 & 1544 & $33^{\circ} 16.14^{\prime}$ & $110^{\circ} 04.04^{\prime}$ & 6.3 & 3.0 & & & & & -0.11 & & & \\
\hline & & & & & & & -1.21 & -1.30 & $\overline{-0.23}$ & $\overline{-1.28}$ & $\overline{-0.16}$ & $\overline{-1.27}$ & $\overline{+0.34}$ & -0.05 \\
\hline
\end{tabular}

For this and all following Tables the residual and travel-time values are in units of seconds and depths, D, in kllometers.

TABLE 2

Crustal Velocity Model.

\begin{tabular}{cc}
\hline$V_{p}(\mathrm{~km} / \mathrm{sec})$ & $\begin{array}{c}\text { Depth to Top } \\
\text { of Layer } \\
(\mathbf{k m})\end{array}$ \\
\hline 5.5 & 0.0 \\
6.3 & 5.5 \\
6.7 & 16.0 \\
7.8 & 32.0 \\
\hline
\end{tabular}

$\mathrm{km}$ east of LJC, JUL is $8 \mathrm{~km}$ north of CUY, and BTL is $8 \mathrm{~km}$ west of BBC. We assume that the delays we have determined from the modern stations are also applicable to the old stations. The elevations and site geology are nearly identical in each case.

As a test, some of the recent earthquakes in the area of the 1937 earthquake southeast of Anza were relocated using only $P$ - and $S$-wave arrival times at stations RVR and CPE and the delays determined for that area. These events all relocated to within $3 \mathrm{~km}$ of their epicenters determined by the more dense local USGS-CIT array. The same test was performed on recent events in the area of the 1954 earthquake using $P$ - and $S$-wave readings from BAR and PLM only. The events relocated to within $2 \mathrm{~km}$ of their catalog epicenters. Thus, we feel that our locations for the 1937 and 1954 events for which good $P$-and $S$-wave readings are available are accurate to within about $5 \mathrm{~km}$. This is a significant improvement over the old location errors of $10 \mathrm{~km}$ or more. 


\section{LARGE EARTHQUAKE LOCATIONS}

The epicenters of significant historic earthquake and aftershock zones on the San Jacinto fault zone are shown in Figure 1. The approximate locations of the $1923\left(M 6 \frac{1}{4}\right), 1918$ ( $M$ 6.8), and $1899(M 7)$ events are based on intensity and limited seismograph data and are discussed by Sanders and Kanamori (1984). The $1915(M$ $6.3), 1940\left(M_{L} 6.7\right)$, and $1979\left(M_{L} 6.6\right)$ earthquakes were caused by rupture of parts

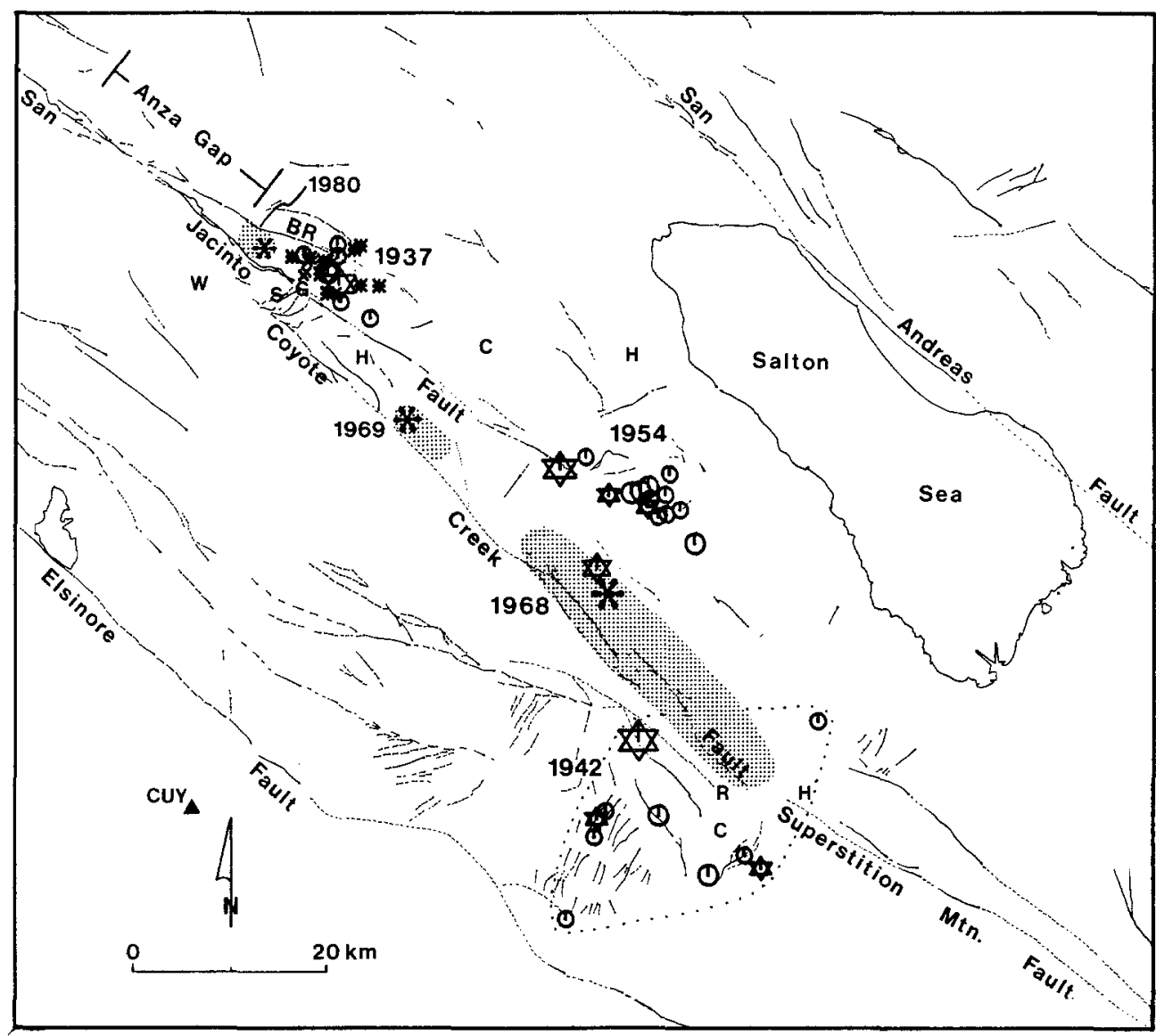

FIG. 3. Map of relocated epicenters of the $1937\left(M_{L} 5.9\right), 1942\left(M_{L} 6.3\right), 1954\left(M_{L} 6.2\right)$ earthquakes and large aftershocks. The aftershock zones of the 1968, 1969, and 1980 earthquakes are shaded and the respective main shock epicenters marked by flower symbols. Previous main shock locations are indicated by single letters. C, CIT catalog; G, Gutenberg (1943); H, Hanks et al. (1975); R, Richter (1958); and S, Sanders and Kanamori (1984). The 1937 catalog location is also the Hileman et al. (1973) location and is about $16 \mathrm{~km}$ southeast of our 1937 epicenter. The 1937 Richter location is coincident with the 1980 main shock epicenter. The 1954 catalog and Richter locations are within $1 \mathrm{~km}$ of our 1954 epicenter and are not plotted. The 1954 Hanks $e t$ al. location is about $14 \mathrm{~km}$ northeast of our 1954 epicenter. BR, Buck Ridge fault. The magnitude symbol key for this and subsequent figures is: $\mathrm{x}, M_{L} 3.0 ;{ }^{*}, M_{L} 3.5 ; \mathbb{1}, M_{L}$ $4.0 ; \mathbb{D}, M_{L} 4.5 ;$ small star, $M_{L} 5.0$; medium star, $M_{L} 5.5$; and large stars, main shocks.

of the Imperial fault, and their locations are discussed by Doser and Kanamori (1986). The aftershock zones of the 1968 Borrego Mountain $\left(M_{L}\right.$ 6.8) and 1969 Coyote Mountain $\left(M_{L} 5.8\right)$ earthquakes are well determined by readings from five regional stations $(\Delta=50$ to $75 \mathrm{~km})$ and tens of temporary stations installed immediately after the main shocks (Allen and Nordquist, 1972; Hamilton, 1972; Thatcher and Hamilton, 1973). 
1937 Buck Ridge Earthquake. We relocated the 25 March 1937 earthquake ( $M_{L}$ 5.9) and aftershocks $\left(M_{L} \geqq 3.0\right)$ using arrival time data from stations RVR and LJC, both about $100 \mathrm{~km}$ distant and $75^{\circ}$ apart in azimuth. We repicked the $P$ - and $S$-wave arrival times from the short-period vertical seismograms and from the Wood-Anderson horizontal seismograms and relocated the events using the delay values appropriate for that area of the fault and those stations (area 2, Figure 2, Table 1). The epicenters of the main shock and most of the aftershocks lie between the surface traces of the San Jacinto and Buck Ridge faults (Figure 3) beneath the physiographic feature called Buck Ridge. We cannot constrain the depths of these events, but the recent seismicity in the area occurs at an average depth of about 12 $\mathrm{km}$. The aftershocks located during the first $2 \mathrm{hr}$ lie northwest of the main shock as do most of the other aftershocks, indicating predominantly unilateral rupture to

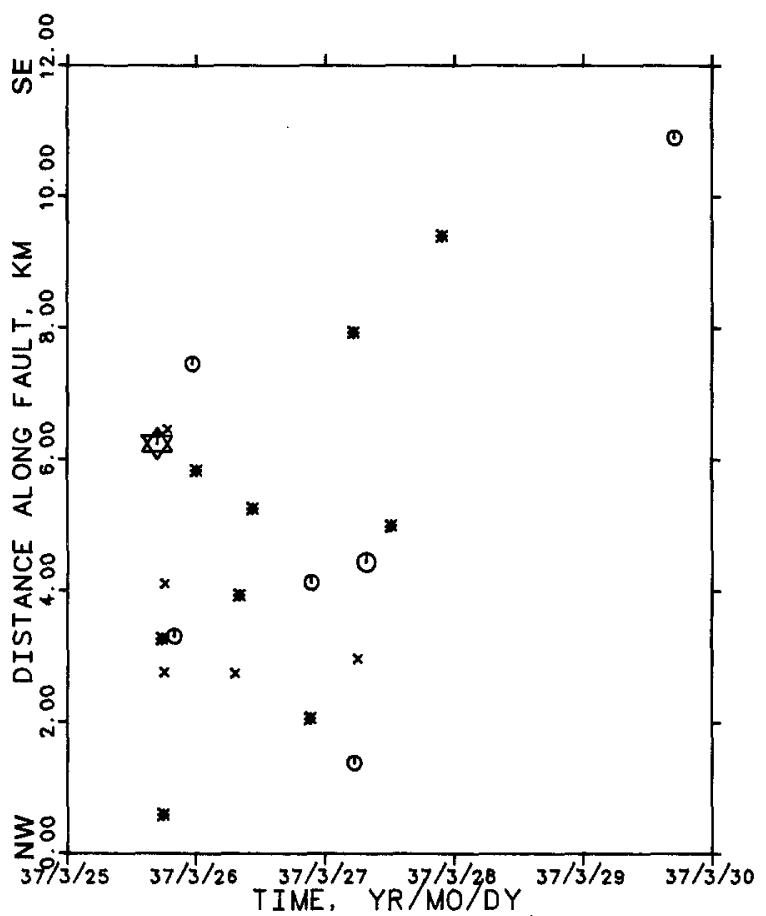

Fig. 4. Time-distance plot of the 1937 earthquake and aftershocks. The distance axis is parallel to the San Jacinto fault. The early aftershocks and most of those in the following 2 days lie northwest of the main shock, suggesting a unilateral rupture length of about $7 \mathrm{~km}$.

the northwest of about $6 \mathrm{~km}$ (Figure 4). Early aftershocks southeast of the main shock suggest perhaps $1 \mathrm{~km}$ of rupture in that direction as well, for a total rupture of about $7 \mathrm{~km}$. The arrival times and new locations for these earthquakes are listed in Table 3. The $P$-wave first motions are consistent with right-slip faulting on a northwest-trending fault (Figure 5).

Previous locations for the 1937 main shock are shown in Figure 3. They span a 30 by $10 \mathrm{~km}$ area and give no consistent indication of the fault which produced this earthquake.

The $1980\left(M_{L} 5.5\right)$ Whitewash earthquake, which is very well located by the dense southern California array, occurred at the northwest end of the 1937 aftershock zone, and its rupture extended another couple of kilometers further northwest (Figure 3). 
TABLE 3

RELocated 1937 MAIN SHOCK AND $M_{L} \geqq 3.0$ AFTERSHOCKS

\begin{tabular}{|c|c|c|c|c|c|c|c|c|c|c|c|}
\hline \multirow{2}{*}{$\mathrm{Yr}-\mathrm{Mo}-\mathrm{Da}$} & \multirow{2}{*}{$\mathrm{HrMn}$} & \multirow{2}{*}{$M_{L}$} & \multicolumn{3}{|c|}{ RVR } & \multicolumn{3}{|c|}{ LJC } & \multirow{2}{*}{ Latitude } & \multirow{2}{*}{ Longitude } & \multirow{2}{*}{ Depth } \\
\hline & & & $P$ & $s$ & $S-P$ & $P$ & $S$ & $S-P$ & & & \\
\hline \multirow[t]{8}{*}{$37-03-25$} & 1649 & 6.0 & 21.26 & 33.68 & 12.42 & 20.70 & & & $33^{\circ} 27.90^{\prime}$ & $116^{\circ} 24.89^{\prime}$ & 12 \\
\hline & 1747 & 3.5 & 25.73 & 37.91 & 12.18 & 25.71 & 37.41 & 11.70 & $33^{\circ} 29.09^{\prime}$ & $116^{\circ} 26.19^{\prime}$ & 12 \\
\hline & 1754 & 3.5 & 51.59 & 63.53 & 11.94 & 51.82 & 63.18 & 11.36 & $33^{\circ} 29.32^{\prime}$ & $116^{\circ} 28.26^{\prime}$ & 12 \\
\hline & 1804 & 3.0 & 46.10 & 57.99 & 11.89 & 45.64 & 57.30 & 11.66 & $33^{\circ} 28.47^{\prime}$ & $116^{\circ} 27.29^{\prime}$ & 12 \\
\hline & 1812 & 3.0 & 31.58 & 43.85 & 12.27 & 31.51 & 43.31 & 11.80 & $33^{\circ} 29.05^{\prime}$ & $116^{\circ} 25.51^{\prime}$ & 12 \\
\hline & 1842 & 3.0 & 26.74 & 39.15 & 12.41 & 25.98 & 37.67 & 11.67 & $33^{\circ} 27.36^{\prime}$ & $116^{\circ} 25.27^{\prime}$ & 12 \\
\hline & 2004 & 4.0 & 24.73 & 36.85 & 12.12 & 24.85 & 36.91 & 12.06 & $33^{\circ} 29.98^{\prime}$ & $116^{\circ} 25.22^{\prime}$ & 12 \\
\hline & 2320 & 4.0 & 43.58 & 56.14 & 12.56 & 42.69 & 54.30 & 11.61 & $33^{\circ} 26.81^{\prime}$ & $116^{\circ} 25.00^{\prime}$ & 12 \\
\hline \multirow[t]{6}{*}{$37-03-26$} & 0010 & 3.5 & 03.30 & 15.69 & 12,39 & 02.61 & 14.14 & 11.53 & $33^{\circ} 27.29^{\prime}$ & $116^{\circ} 25.89^{\prime}$ & 12 \\
\hline & 0717 & 3.0 & 43.01 & 55.04 & 12.03 & 42.68 & 54.14 & 11.46 & $33^{\circ} 28.29^{\prime}$ & $116^{\circ} 27.49^{\prime}$ & 12 \\
\hline & 0806 & 3.5 & 36.96 & 49.31 & 12.35 & 36.85 & 48.31 & 11.46 & $33^{\circ} 28.38^{\prime}$ & $116^{\circ} 26.37^{\prime}$ & 12 \\
\hline & 1033 & 3.5 & 19.77 & 32.12 & 12.35 & 19.80 & 32.08 & 12.28 & $33^{\circ} 29.89^{\prime}$ & $116^{\circ} 23.65^{\prime}$ & 12 \\
\hline & 2117 & 3.5 & 48.40 & 60.42 & 12.02 & 48.45 & 60.07 & 11.62 & $33^{\circ} 29.27^{\prime}$ & $116^{\circ} 27.04^{\prime}$ & 12 \\
\hline & 2124 & 4.0 & 11.93 & 24.04 & 12.11 & 11.73 & 23.79 & 12.06 & $33^{\circ} 29.34^{\prime}$ & $116^{\circ} 25.19^{\prime}$ & 12 \\
\hline \multirow[t]{6}{*}{$37-03-27$} & 0524 & 3.5 & 36.91 & 49.62 & 12.71 & 36.37 & 48.24 & 11.87 & $33^{\circ} 27.71^{\prime}$ & $116^{\circ} 23.63^{\prime}$ & 12 \\
\hline & 0528 & 4.0 & 59.9 & 71.8 & 11.9 & 59.96 & 71.58 & 11.62 & $33^{\circ} 29.41^{\prime}$ & $116^{\circ} 27.48^{\prime}$ & 12 \\
\hline & 0607 & 3.0 & 30.76 & 43.03 & 12.27 & 30.99 & 42.62 & 11.63 & $33^{\circ} 29.38^{\prime}$ & $116^{\circ} 26.14^{\prime}$ & 12 \\
\hline & 0742 & 4.5 & 36.90 & 49.10 & 12.20 & 36.52 & 48.27 & 11.75 & $33^{\circ} 28.43^{\prime}$ & $116^{\circ} 25.88^{\prime}$ & 12 \\
\hline & 1227 & 3.5 & 41.85 & 54.33 & 12.48 & 42.05 & 54.07 & 12.02 & $33^{\circ} 29.69^{\prime}$ & $116^{\circ} 24.08^{\prime}$ & 12 \\
\hline & 2150 & 3.5 & 20.54 & 33.16 & 12.62 & 19.61 & 31.93 & 12.32 & $33^{\circ} 27.67^{\prime}$ & $116^{\circ} 22.41^{\prime}$ & 12 \\
\hline $37-03-29$ & 1703 & 4.0 & 33.31 & 46.35 & 13.04 & 32.20 & 43.90 & 11.70 & $33^{\circ} 25.91^{\prime}$ & $116^{\circ} 22.97^{\prime}$ & 12 \\
\hline
\end{tabular}

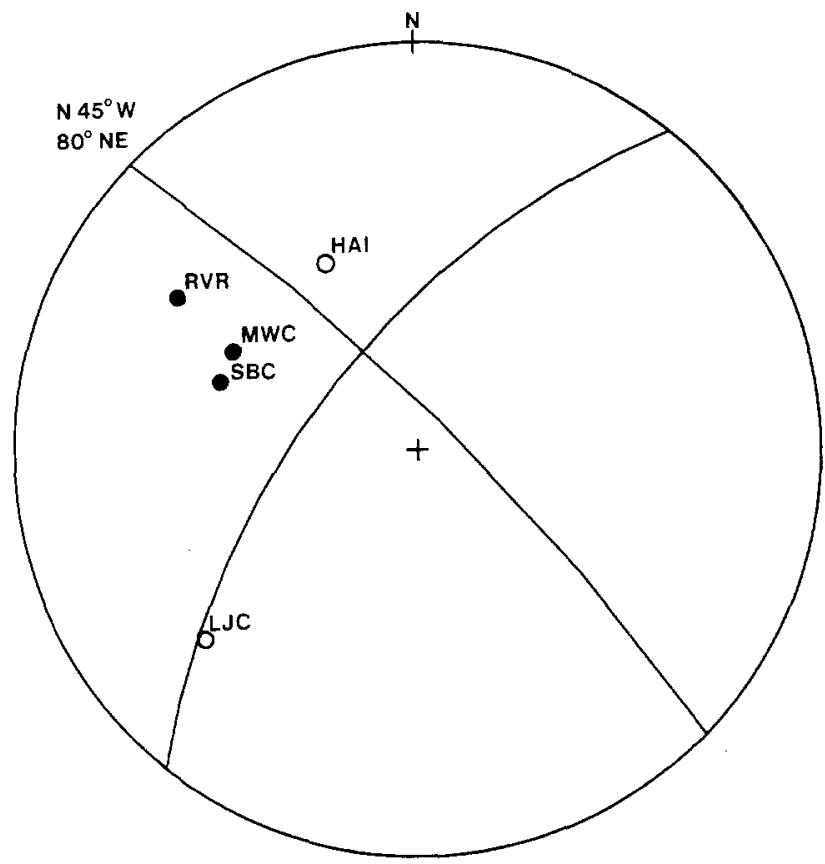

FIG. 5. $P$-wave first motion source mechanism for the 1937 Buck Ridge earthquake. Solid circles, compression; open circles, dilatation. Lower hemisphere, equal-angle projection. The southern California seismograph stations are Haiwee (HAI), La Jolla (LJC), Mount Wilson (MWC), Riverside (RVR), and Santa Barbara (SBC). Station LJC is nodal. 
We also relocated most of the $M_{L} \geqq 3.0$ seismicity from January 1932 through 24 March 1937, which are given a CIT catalog location inside the box shown in Figure 6 . The earthquakes are relocated using arrival times from the original phase cards, and their new locations are listed in Table 4 and shown in Figure 6. Four main areas of earthquake concentration are seen: in the epicentral region of the 1937 main shock; beneath the Cahuilla Valley area; on the San Jacinto fault north of Anza; and in the general area of the future 1954 and 1968 events. The time-distance

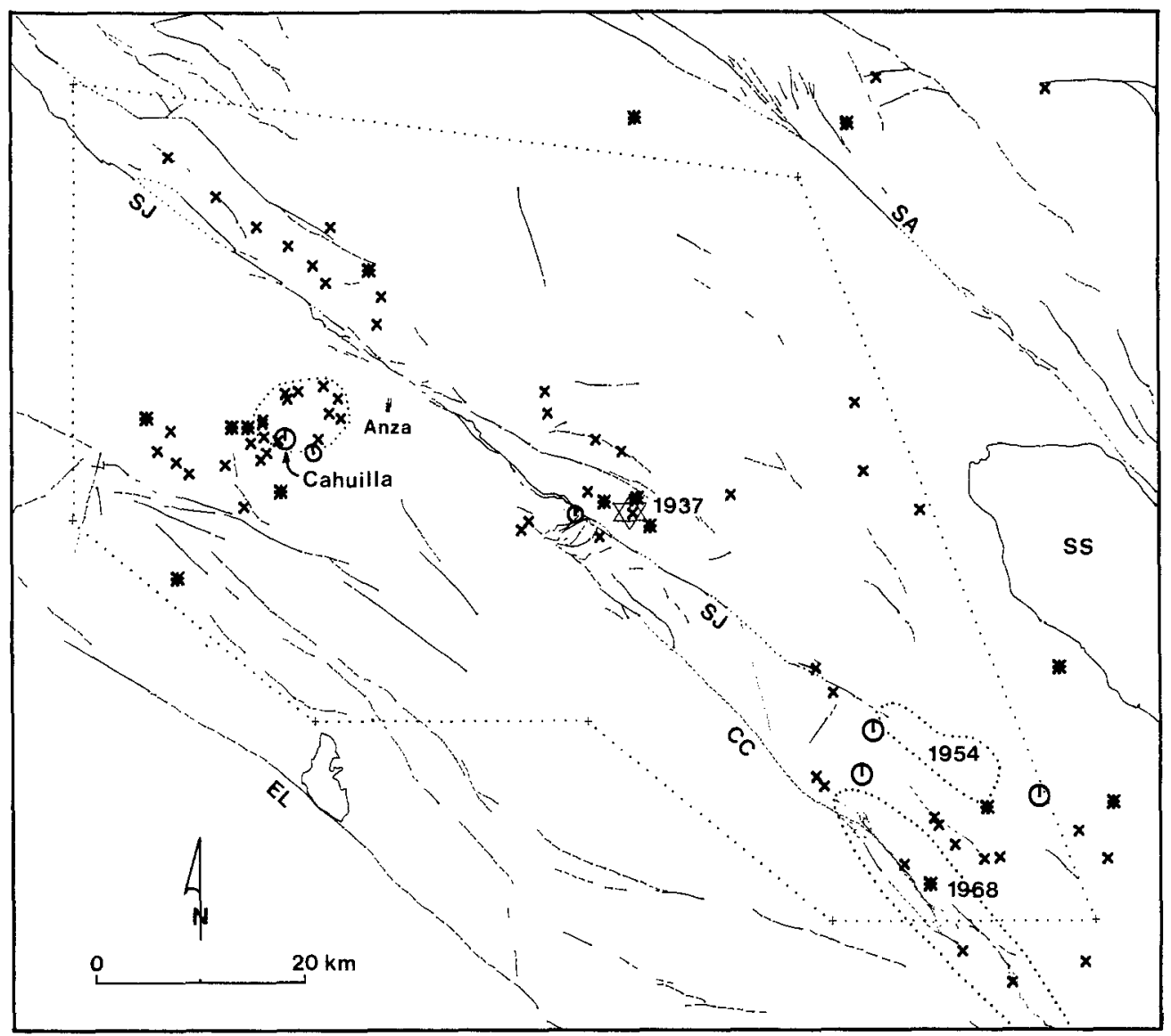

FIG. 6. Relocated epicenters of $M_{L} \geqq 3.0$ earthquakes near the southern San Jacinto fault in the time period January 1932 to March 1937 . The catalog locations of the earthquakes are all within the box described by the dotted line segments. The 1937 main shock and the 1954 and 1968 rupture zones are indicated.

plot (Figure 7) illustrates the relationships of the pre-1937 seismicity. Some preshock activity is concentrated in the rupture zone of the 1937 event with very little activity for about $20 \mathrm{~km}$ or more on either side. These earthquakes stopped about 1 yr before the main shock. The cluster of activity at Cahuilla began abruptly about $1 \frac{1}{2} \mathrm{yr}$ before the 1937 earthquake and continued until about 4 months before the $M_{L}$ 5.9 main shock. This cluster of activity is outlined in Figure 6 . The concentration of activity near Cahuilla is interesting because many of the events were clustered in time with five ( $M_{L} 3.0$ to 4.5$)$ occurring on 4 November 1935 and five more $\left(M_{L}\right.$ 3.0) during the following week. This increase in activity at Cahuilla in the $1 \frac{1}{2} \mathrm{yr}$ 
TABLE 4. Relocated 1932-1937,3,24 Activity

\begin{tabular}{|c|c|c|c|c|c|c|c|c|c|c|c|}
\hline \multirow[b]{2}{*}{ YR MO DA } & \multirow[b]{2}{*}{ HRMN } & \multirow[b]{2}{*}{$\mathrm{M}_{\mathrm{L}}$} & \multicolumn{3}{|c|}{ RVR } & \multicolumn{3}{|c|}{ LJC } & \multirow[b]{2}{*}{ LAT } & \multirow[b]{2}{*}{ LON } & \multirow[b]{2}{*}{ D } \\
\hline & & & $\mathrm{P}$ & $S$ & $S-P$ & $\mathbf{P}$ & $\mathrm{S}$ & $\mathrm{S}-\mathrm{P}$ & & & \\
\hline 320110 & 1539 & 3.0 & & & 8.0 & & & & $33^{\circ} 41.5^{\prime}$ & $116^{\circ} 46.5^{\circ}$ & - \\
\hline 320710 & 0833 & 3.0 & & & 13.5 & & & 14.0 & $33^{\circ} 33.5^{\prime}$ & $116^{\circ} 11.5^{\prime}$ & - \\
\hline 320905 & 0832 & 3.0 & 57.7 & 60.1 & 11.4 & 59.5 & 70.8 & 11.3 & $33^{\circ} 33.0^{\circ}$ & $110^{\circ} 30.5^{\prime}$ & 12 \\
\hline 321002 & 0448 & 3.0 & & & 16.8 & & & 13.5 & $33^{\circ} 12^{\prime}$ & $116^{\circ} 00.5^{\prime}$ & + \\
\hline 321002 & 1623 & 3.0 & & & 10.1 & & & 12.1 & $33^{\circ} 14^{\prime}$ & $116^{\circ} 13.5^{\circ}$ & + \\
\hline 321010 & 2312 & 3.0 & & & 15.2 & & & 13.5 & $33^{\circ} 28^{\prime}$ & $116^{\circ}$ o7. $5^{\prime}$ & - \\
\hline $3211 \quad 16$ & 0047 & 3.0 & & & 7.3 & & & & $33^{\circ} 42.5^{\prime}$ & $116^{\circ} 48.5^{\prime}$ & - \\
\hline 321200 & 1304 & 3.5 & 45.4 & 53.7 & 8.3 & 48.3 & 57.8 & 9.5 & $33^{\circ} 32.7^{\prime}$ & $110^{\circ} 55.3^{\prime}$ & 4 \\
\hline 321220 & 1931 & 3.5 & & & 17.5 & & & 15 & $33^{\circ} 20^{\prime}$ & $115^{\circ} 59^{\prime}$ & - \\
\hline $3801 \quad 18$ & 1921 & 3.0 & & & 16.8 & & & 13 & $33^{\circ} 10^{\prime}$ & $116^{\circ} 08.6^{\prime}$ & - \\
\hline 330131 & 2081 & 3.5 & & & 10.8 & & & 15 & $33^{\circ} 48^{\prime}$ & $116^{\circ} 25^{\circ}$ & - \\
\hline 330308 & 1058 & 3.5 & & & 11.8 & & & 11.5 & $33^{\circ} 28.5^{\circ}$ & $110^{\circ} 27^{\prime}$ & + \\
\hline 330805 & 2331 & 4.4 & 38.4 & 54.7 & 16.3 & 34.9 & 47.4 & 12.5 & $33^{\circ} 16.8^{\prime}$ & $116^{\circ} 10.5^{\prime}$ & 10 \\
\hline 330806 & 0332 & 4.7 & 53.6 & 68.8 & 16.2 & 49.1 & & & $33^{\circ} 14.6^{\circ}$ & $116^{\circ} 11.2^{\prime}$ & 10 \\
\hline 331005 & 2020 & 3.0 & 30.3 & 45.7 & 9.4 & 38.1 & 45.7 & 9.6 & $33^{\circ} 28.2^{\prime}$ & $116^{\circ} 49.3^{\circ}$ & 4 \\
\hline 331005 & 2220 & 2.8 & 51.0 & 89.1 & 18.1 & 44.3 & 57.4 & 13.1 & $33^{\circ} 05.6^{\prime}$ & $110^{\circ} 05.1^{\prime}$ & 10 \\
\hline 331021 & 0408 & 3.3 & & & 0.3 & & & 8.8 & $33^{\circ} 24.6^{\prime}$ & $118^{\circ} 53.4^{\prime}$ & - \\
\hline 331222 & 0818 & 3.0 & 54.5 & 65.6 & 11.1 & 53.2 & 64.6 & 11.2 & $33^{\circ} 27.1^{\circ}$ & $116^{\circ} 32.1^{\prime}$ & 10 \\
\hline 340118 & 2228 & 3.5 & 16.0 & 24.7 & 8.7 & 21.0 & 32.7 & 11.7 & $33^{\circ} 40.2^{\prime}$ & $116^{\circ} 41.5^{\prime}$ & 18 \\
\hline 340207 & 0927 & 3.2 & 48.9 & 60.0 & 11.1 & 50.8 & 62.5 & 11.8 & $33^{\circ} 34.1^{\prime}$ & $110^{\circ} 30.7^{\prime}$ & 12 \\
\hline 340220 & 1035 & 4.0 & 21.2 & 32.8 & 11.6 & 20.3 & 31.7 & 11.4 & $33^{\circ} 27.8^{\prime \prime}$ & $116^{\circ} 28.8^{\prime}$ & 12 \\
\hline 340302 & 1940 & 3.0 & & & 13.2 & & & 12.2 & $33^{\circ} 28.8^{\prime}$ & $118^{\circ} 19.2^{\prime}$ & - \\
\hline 340407 & 1343 & 3.0 & 30.2 & 54.8 & 18.6 & 29.3 & 44.2 & 14.9 & $33^{\circ} 05.0^{\circ}$ & $115^{\circ} 57.5^{\prime}$ & 10 \\
\hline 340408 & 1014 & 3.0 & 44.8 & 52.8 & 8.1 & 48.1 & 80.5 & 12.4 & $33^{\circ} 38.8^{\prime}$ & $118^{\circ} 40.8^{\prime}$ & 16 \\
\hline 340002 & 2115 & 3.0 & 05.7 & 84.1 & 18.4 & 60.8 & 75.5 & 14.6 & $33^{\circ} 11.7^{\prime \prime}$ & $115^{\circ} 57 . \theta^{\prime}$ & 10 \\
\hline 34 o7 22 & 0718 & 3.0 & 41.9 & 50.2 & 8.3 & 48.8 & 58.2 & 11.4 & $33^{\circ} 39.6^{\prime}$ & $110^{\circ} 44.2^{\circ}$ & 18 \\
\hline 340814 & 1129 & 3.5 & & & 17.8 & & & & $33^{\circ} 09^{\prime}$ & $110^{\circ} 07^{\prime}$ & - \\
\hline 340902 & 1016 & 3.0 & & & 14.3 & & & 13.8 & $33^{\circ} 30^{\prime}$ & $110^{\circ} 11^{\prime}$ & - \\
\hline 341030 & 0451 & 3.0 & 57.2 & 85.8 & $8 . \theta$ & 59.1 & 88.4 & 8.3 & $33^{\circ} 31.1^{\prime \prime}$ & $116^{\circ} 54.6^{\prime}$ & 4 \\
\hline 341115 & 0717 & 3.5 & 47.2 & 84.8 & 17.7 & 42.7 & 58.2 & 13.5 & $33^{\circ} 12.9^{\prime \prime}$ & $110^{\circ} 03.5^{\prime}$ & 10 \\
\hline 341207 & 0334 & 3.0 & 35.7 & 48.0 & 12.3 & 35.0 & 40.7 & 11.7 & $33^{\circ} 27.9^{\prime}$ & $110^{\circ} 25.3^{\prime}$ & 12 \\
\hline 341221 & 1224 & 3.0 & & & 6.3 & & & & $33^{\circ} 46^{\prime}$ & $116^{\circ} 54^{\circ}$ & - \\
\hline 350129 & 2104 & 3.0 & 55.1 & 70.5 & 15.4 & 51.7 & 84.3 & 12.8 & $33^{\circ} 18.8^{\circ}$ & $110^{\circ} 12.9^{\prime}$ & 10 \\
\hline $\begin{array}{lll}35 & 08 & 12\end{array}$ & 1351 & 3.0 & 06.7 & 14.0 & 7.9 & 12.5 & 24.0 & 12.1 & $33^{\circ} 42.5^{\prime}$ & $116^{\circ} 43.9^{\prime}$ & 10 \\
\hline 350407 & 0032 & 3.5 & 18.2 & 31.5 & 12.3 & 18.8 & 30.6 & 11.8 & $33^{\circ} 28.7^{\prime}$ & $110^{\circ} 25.0^{\prime}$ & 12 \\
\hline 350415 & 0421 & 3.0 & 58.9 & 70.3 & 19.4 & 52.7 & 66.8 & 14.2 & $33^{\circ} 10.2^{\circ}$ & $115^{\circ} 58.1^{\circ}$ & 10 \\
\hline 350527 & 0843 & 3.0 & 10.0 & 21.7 & 11.7 & 10.8 & 22.6 & 11.7 & $33^{\circ} 31.7^{\prime}$ & $116^{\circ} 278^{\circ}$ & 12 \\
\hline 350715 & 1002 & 3.0 & 38.9 & 47.9 & 9.0 & 40.0 & 50.6 & 10.6 & $33^{\circ} 31.6^{\prime}$ & $110^{\circ} 47.1^{\prime}$ & 4 \\
\hline 350822 & 1624 & 3.0 & & & 12.5 & & & 17.1 & $33^{\circ} 50^{\prime}$ & $116^{\circ} 10^{\prime}$ & + \\
\hline 350202 & 0344 & 3.0 & & & 9.2 & & & & $33^{\circ} 31.8^{\prime}$ & $118^{\circ} 48^{\prime}$ & - \\
\hline 351018 & 1350 & 3.0 & 52.9 & 70.8 & 17.8 & 47.6 & 61,0 & 13.4 & $33^{\circ} 10.3^{\prime}$ & $110^{\circ} 03.7^{\prime \prime}$ & 10 \\
\hline $\begin{array}{llll}35 & 11 & 02\end{array}$ & 1734 & 3.5 & 24.5 & 37.3 & 12.8 & 23.9 & 35.4 & 11.5 & $33^{\circ} 27.3^{\prime}$ & $110^{\circ} 24.2^{\prime}$ & 12 \\
\hline $\begin{array}{lll}35 & 11 & 04\end{array}$ & 0355 & 4.5 & 03.6 & 72.6 & 9.1 & 64.8 & 75.4 & 10.6 & $33^{\circ} 31.7^{\prime \prime}$ & $116^{\circ} 46.7^{\prime}$ & 4 \\
\hline 351104 & 0547 & 3.0 & 64.6 & 73.5 & 8.9 & 86.8 & 78,0 & 11.1 & $33^{\circ} 34.1^{\prime}$ & $110^{\circ} 45.9^{\circ}$ & 4 \\
\hline $\begin{array}{llll}35 & 11 & 04\end{array}$ & 0857 & 3.0 & 70.0 & 85.4 & 8.4 & 78.1 & 89.3 & 11.2 & $33^{\circ} 33.8^{\prime}$ & $110^{\mathrm{o}} 43.4^{\prime}$ & 4 \\
\hline 351104 & 0714 & 3.0 & 53.4 & 03.1 & 0.7 & 56.2 & 60.1 & 10.9 & $33^{\circ} 32.7^{\prime}$ & $110^{\circ} 43.2^{\prime}$ & 4 \\
\hline 351104 & 0011 & 3.0 & 47.6 & 58.6 & 0.0 & 40.5 & 50.0 & 10.4 & $33^{\circ} 32.5^{\prime}$ & $110^{\circ} 48.1^{\prime}$ & 4 \\
\hline 351108 & 1002 & 3.0 & 18.7 & $2 \pi .7$ & 9.0 & 20.9 & 32.3 & 11.4 & $33^{\circ} 34.4^{\prime}$ & $116^{\circ} 44.4^{\prime}$ & 4 \\
\hline $35 \quad 11 \quad 10$ & 0021 & 3.0 & 19.8 & 28.7 & 8.8 & 21.7 & & & $33^{\circ} 32.7^{*}$ & $110^{\circ} 48.1^{\prime}$ & 4 \\
\hline 351111 & 1544 & 3.0 & 51.3 & 01.6 & 8.3 & 52.4 & 02.4 & 10.0 & $33^{\circ} 30.6^{\prime}$ & $116^{\circ} 48.3^{\prime}$ & 4 \\
\hline $\begin{array}{lll}35 & 11 & 12\end{array}$ & 1145 & 3.0 & 33.1 & 42.5 & 0.4 & 34.2 & 45.0 & 10.8 & $33^{\circ} 31.7$ & $116^{\circ} 44.7^{x}$ & 4 \\
\hline $3511 \quad 12$ & 1346 & 3.0 & 48.2 & 57.0 & 8.8 & 50.5 & 61.5 & 11.0 & $33^{\circ} 34.0^{\prime}$ & $110^{\circ} 46.7^{\circ}$ & 4 \\
\hline 351119 & 2205 & 3.0 & & & 8.9 & & & & $33^{\circ} 33.7^{\prime}$ & $110^{\circ} 40.0^{\prime}$ & - \\
\hline 351120 & 1610 & 3.0 & & & 7.0 & & & & $33^{\circ} 44^{\prime}$ & $116^{\circ} 51^{\prime}$ & - \\
\hline 351124 & 2352 & 3.0 & & & 8.2 & & & & $33^{\circ} 40.5^{\prime}$ & $116^{\circ} 45^{\prime}$ & - \\
\hline 351120 & 1200 & 3.0 & & & 9.7 & & & & $33^{\circ} 33^{\circ}$ & $118^{\circ} 44^{*}$ & - \\
\hline 300124 & 1749 & 3.0 & & & 10 & & & & $33^{\circ} 14.5^{\prime}$ & $116^{\circ} 14^{\prime}$ & - \\
\hline 360126 & 1413 & 3.0 & 33.6 & 44.6 & 11.0 & 32.3 & 44.0 & 11.7 & $33^{\circ} 27.5^{\prime}$ & $116^{\circ} 31.7$ & 10 \\
\hline 360130 & 1714 & 3.0 & 31.9 & & & 28.6 & & & $33^{\circ} 20^{\circ}$ & $116^{\circ} 14^{\prime \prime}$ & - \\
\hline 360131 & 0909 & 3.0 & & & 11.5 & & & 11.2 & $33^{\circ} 2 \theta^{\prime}$ & $110^{\circ} 28$ & + \\
\hline
\end{tabular}

before the 1937 earthquake has been commented on by Sanders and Kanamori (1984), since a similar increase has occurred recently and also may have preceded the nearby 1918 ( $M$ 7) San Jacinto-Hemet earthquake.

1954 Arroyo Salada Earthquake. We relocated the 19 March 1954 earthquake $\left(M_{L} 6.2\right)$ using $P$-wave arrival times at stations PLM, BAR, RVR, and BBC, ranging in distance from 60 to $140 \mathrm{~km}$ and spanning $110^{\circ}$ in azimuth. The $M_{L} \geqq 3.9$ aftershocks were relocated using $P$ - and $S$-wave arrival times recorded at stations 


\begin{tabular}{|c|c|c|c|c|c|c|c|c|c|c|c|}
\hline \multirow[b]{2}{*}{ YR MO DA } & \multirow[b]{2}{*}{ HRMN } & \multirow[b]{2}{*}{$\mathrm{M}_{\mathrm{L}}$} & \multicolumn{3}{|c|}{ RVR } & \multicolumn{3}{|c|}{$\mathrm{LJC}$} & \multirow[b]{2}{*}{ LAT } & \multirow[b]{2}{*}{ LON } & \multirow[b]{2}{*}{$\mathrm{D}$} \\
\hline & & & $P$ & $\mathrm{~S}$ & $S-P$ & $\mathbf{P}$ & $\mathrm{S}$ & S-P & & & \\
\hline 360201 & 0.501 & 3.0 & & & 9.0 & & & 11.3 & $33^{\circ} 37.5^{\prime}$ & $110^{\circ} 41^{\prime}$ & + \\
\hline 330205 & 2100 & 3.0 & 55.8 & 64.6 & 8.8 & 58.7 & $\theta 0.2$ & 0.5 & $33^{\circ} 29.8^{x}$ & $110^{\circ} 52.7$ & 4 \\
\hline 360208 & 0813 & 3.0 & 57.0 & 68.4 & 12.4 & 58.1 & 69.6 & 11.5 & $33^{\circ} 31.1^{\prime}$ & $110^{\circ} 25.8^{\prime}$ & 12 \\
\hline 360206 & 1858 & 3.5 & 32.1 & 51.0 & 18.9 & 28.2 & 42.9 & 14.7 & $33^{\circ} 13.1^{\circ}$ & $115^{\circ} 55.7^{\prime}$ & 10 \\
\hline 380210 & 0948 & 3.0 & 40.0 & 48.8 & 9.8 & 41.9 & 51.5 & 0.0 & $33^{\circ} 31.0^{\prime \prime}$ & $116^{\circ} 47.9^{\prime}$ & 4 \\
\hline $36 \quad 03 \quad 17$ & 1227 & 3.0 & & & 8.7 & & & 8.0 & $33^{\circ} 30.5^{\prime}$ & $116^{\circ} 53.5^{\prime}$ & + \\
\hline $30031 \theta$ & 1639 & 3.5 & & & 9.5 & & & 9.8 & $33^{\circ} 2 \theta^{\circ}$ & $110^{\circ} 47^{\prime}$ & + \\
\hline 380405 & 1958 & 3.0 & 31.3 & 43.5 & 12.2 & 30.3 & & & $33^{\circ} 26.7^{\prime \prime}$ & $110^{\circ} 27.3^{\prime}$ & 12 \\
\hline 300507 & 0348 & 3.5 & 68.6 & 89.2 & 20.6 & 58.4 & 75.9 & 16.5 & $32^{\circ} 52.0^{\prime}$ & $115^{\circ} 49.8^{\prime}$ & 10 \\
\hline $\begin{array}{lll}36 & 0507\end{array}$ & 1147 & 4.5 & 51.5 & 60.5 & 18.0 & 47.1 & 61.3 & 14.2 & $33^{\circ} 13.5^{\prime}$ & $118^{\circ} 00.3^{\prime}$ & 10 \\
\hline 360507 & 1446 & 3.0 & 12.5 & 28.2 & 16.7 & 7.0 & 20.5 & 13.5 & $33^{\circ} 12.4^{\prime \prime}$ & $110^{\circ} 06.8^{\prime}$ & 10 \\
\hline 300512 & 1208 & 3.0 & 13.7 & 23.0 & 9.3 & 15.5 & 25.4 & 9.8 & $33^{\circ} 31.5^{\prime \prime}$ & $116^{\circ} 48.8^{\prime}$ & 4 \\
\hline 380014 & 2305 & 3.0 & & & 17.0 & & & 13.5 & $33^{\circ} 11^{\prime}$ & $110^{\circ} 05.5^{\prime}$ & + \\
\hline 300821 & 1418 & 3.5 & & & 8.0 & & & 10.3 & $33^{\circ} 32.3^{\prime}$ & $110^{\circ} 4 \theta^{\prime}$ & + \\
\hline 38 or 28 & 1422 & 4.0 & & & 8.5 & & & & $33^{\circ} 31^{\prime}$ & $116^{\circ} 45^{\prime}$ & - \\
\hline 300810 & 0759 & 3.0 & 43.3 & 58.3 & 15.0 & 47.3 & 85.4 & 18.1 & $33^{\circ} 49.4^{\prime}$ & $115^{\circ} 59.5^{\circ}$ & 16 \\
\hline 300810 & 1318 & 3.0 & 46.0 & 55.2 & 9.2 & 47.0 & 58.8 & 9.8 & $33^{\circ} 30.4^{\prime}$ & $110^{\circ} 50.4^{\prime}$ & 4 \\
\hline 300905 & 1024 & 3.5 & & & 8.8 & & & 10.0 & $33^{\circ} 32.3^{\prime}$ & $110^{\circ} 50^{\prime}$ & + \\
\hline 360911 & 0932 & 3.0 & & & 19 & & & 12.8 & $33^{\circ} 04^{\prime}$ & $118^{\circ} 02^{\prime}$ & - \\
\hline 361014 & 0630 & 3.5 & 27,2 & 40.1 & 12.8 & 31.8 & 48.4 & 16.5 & $33^{\circ} 47.7^{\prime}$ & $116^{\circ} 11.8^{\prime}$ & 16 \\
\hline 381202 & 0433 & 3.0 & 40.1 & 48.5 & 8.4 & 42.3 & 52.0 & 8.7 & $33^{\circ} 32.1^{\prime}$ & $110^{\circ} 53.8^{\circ}$ & 4 \\
\hline $36 \quad 1207$ & 2344 & 3.0 & 29.0 & 48.6 & 17.6 & 23.2 & 37.2 & 14.0 & $33^{\circ} 10.4^{\prime}$ & $110^{\circ} 02.7^{\prime}$ & 10 \\
\hline
\end{tabular}

In the depth, $D$, column the numbers indicate the assumed depth based on local seismicity and used in the location calculations. + means good relative location based on two S-P values. - means poor relative location.

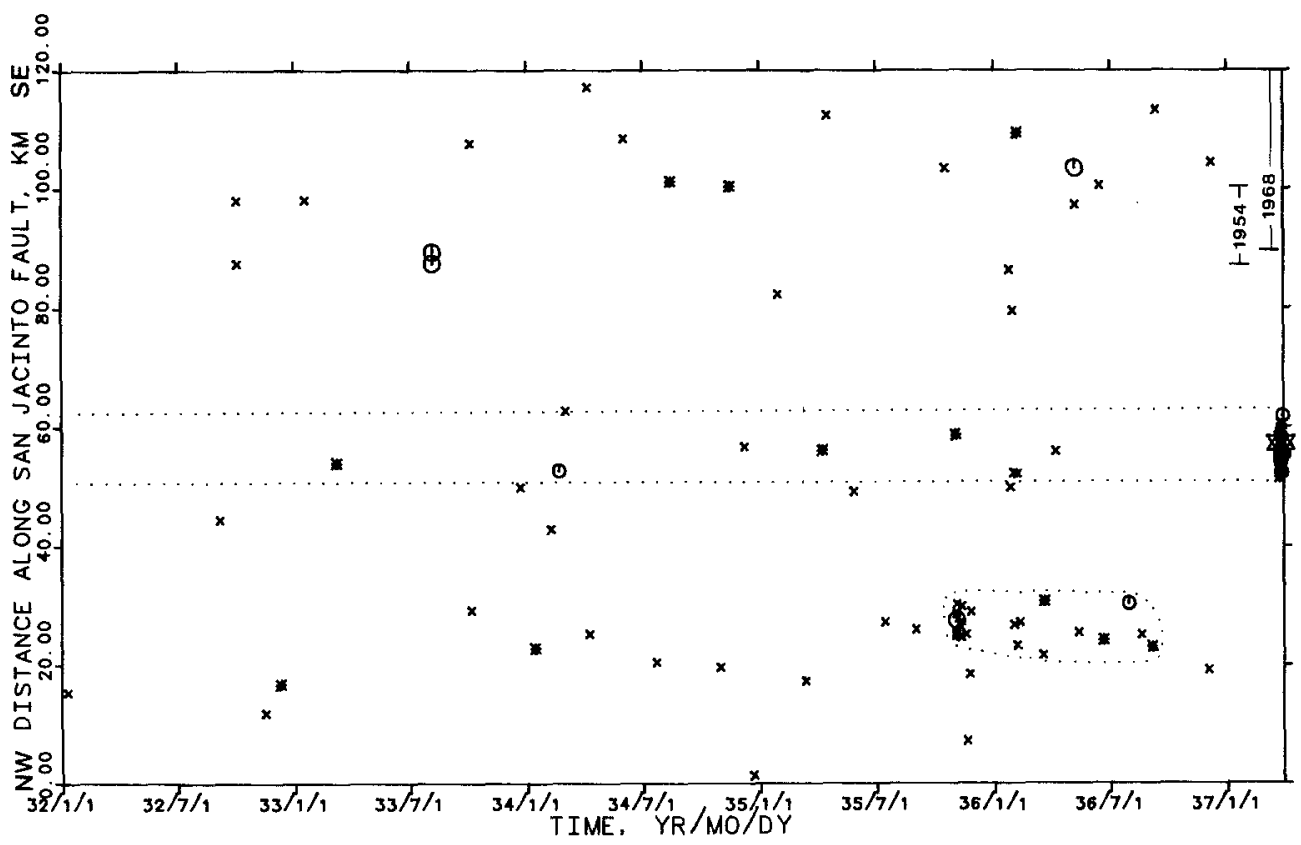

FrG. 7. Time-distance plots of earthquakes shown on Figure 6. The distance axis parallels the San Jacinto fault. All earthquakes in Figure 6 are plotted except for the eight northeasternmost and the one southwesternmost. The 1937 aftershock zone is marked. The Cahuilla cluster is outlined. The future rupture zones of the 1954 and 1968 earthquakes are indicated.

PLM and BAR, both about $75 \mathrm{~km}$ distant and $60^{\circ}$ apart in azimuth. Except for the main shock, all of the arrival times were obtained from the original phase cards. The delays used are those determined for the area numbered 8 in Figure 2 and Table 1. The new epicenters are shown in Figure 3 and listed in Table 5. The main shock is located at the southeastern mapped termination of the San Jacinto (Clark) 
fault, and the aftershocks extend about $15 \mathrm{~km}$ further southeast beneath Arroyo Salada indicating unilateral rupture to the southeast. Most of the aftershocks cluster at the southeast end of the apparent rupture zone. One of the largest aftershocks $\left(M_{L} 5.5\right)$ occurred near or on the Coyote Creek fault near the future epicenter of the 1968 Borrego Mountain earthquake. The original main shock location by Richter (1958) is essentially identical to ours, but the relocation by Hanks et al. (1975) lies about $14 \mathrm{~km}$ northeast (Figure 3). The $P$-wave first motions constrain a source mechanism that indicates right-slip on a $N 56^{\circ} \mathrm{W}$ trending fault (Figure 8).

TABLE 5

Relocated 1954 Main Shock, $M_{L} \geqq 3.9$ Aftershocks, and A Preshock Cluster

\begin{tabular}{|c|c|c|c|c|c|c|c|c|c|c|c|}
\hline \multirow{2}{*}{ Yr-Mo-Da } & \multirow{2}{*}{$\mathrm{HrMn}$} & \multirow{2}{*}{$M_{L}$} & \multicolumn{2}{|c|}{ PLM } & \multicolumn{2}{|c|}{ BAR } & \multirow{2}{*}{$\begin{array}{c}\mathrm{RVR} \\
P\end{array}$} & \multirow{2}{*}{$\begin{array}{c}\mathrm{BBC} \\
P\end{array}$} & \multirow{2}{*}{ Latitude } & \multirow{2}{*}{ Longitude } & \multirow{2}{*}{ Depth } \\
\hline & & & $P$ & $\bar{S}$ & $P$ & $s$ & & & & & \\
\hline \multirow[t]{5}{*}{$54-01-04$} & 1513 & 3.1 & 40.90 & 48.90 & 42.60 & 52.70 & & & $33^{\circ} 17.71^{\prime}$ & $116^{\circ} 08.35^{\prime}$ & 8 \\
\hline & 1850 & 3.9 & 68.40 & & 69.90 & 79.60 & & & $33^{\circ} 16.00^{\prime}$ & $116^{\circ} 06.00^{\prime}$ & 8 \\
\hline & 1949 & 3.0 & 20.50 & 29.00 & 21.80 & 31.60 & & & $33^{\circ} 15.97^{\prime}$ & $116^{\circ} 06.82^{\prime}$ & 8 \\
\hline & 2106 & 3.0 & 22.70 & 30.90 & 24.60 & 34.50 & & & $33^{\circ} 17.59^{\prime}$ & $116^{\circ} 08.28^{\prime}$ & 8 \\
\hline & 2331 & 4.2 & 63.90 & & 65.90 & 75.80 & & & $33^{\circ} 17.63^{\prime}$ & $116^{\circ} 06.77^{\prime}$ & 8 \\
\hline $54-01-07$ & 2122 & 3.2 & 22.30 & 30.90 & 24.50 & 34.40 & & & $33^{\circ} 18.09^{\prime}$ & $116^{\circ} 07.23^{\prime}$ & 8 \\
\hline \multirow[t]{10}{*}{$54-03-19$} & 0954 & 6.2 & 40.30 & & 42.60 & & 51.20 & 49.70 & $33^{\circ} 17.73^{\prime}$ & $116^{\circ} 10.58^{\prime}$ & 8 \\
\hline & 1015 & 4.5 & 32.80 & 42.30 & 34.90 & 44.50 & & & $33^{\circ} 16.75^{\prime}$ & $116^{\circ} 04.64^{\prime}$ & 8 \\
\hline & 1020 & 4.5 & 8.00 & 16.80 & 9.30 & 19.40 & & & $33^{\circ} 16.52^{\prime}$ & $116^{\circ} 05.16^{\prime}$ & 8 \\
\hline & 1021 & 5.5 & 28.60 & 37.20 & 29.30 & & & & $33^{\circ} 12.49^{\prime}$ & $116^{\circ} 08.17^{\prime}$ & 8 \\
\hline & 1026 & 4.0 & & 30.70 & 23.00 & 33.30 & & & $33^{\circ} 17.48^{\prime}$ & $116^{\circ} 03.24^{\prime}$ & 8 \\
\hline & 1201 & 3.9 & 28.50 & & 29.90 & 39.80 & & & $33^{\circ} 16.10^{\prime}$ & $116^{\circ} 04.53^{\prime}$ & 8 \\
\hline & 1308 & 4.3 & 15.30 & 25.30 & 16.10 & 25.80 & & & $33^{\circ} 13.70^{\prime}$ & $116^{\circ} 01.49^{\prime}$ & 8 \\
\hline & 1401 & 4.1 & 8.80 & & 9.90 & 19.80 & & & $33^{\circ} 15.28^{\prime}$ & $116^{\circ} 03.43^{\prime}$ & 8 \\
\hline & 1438 & 4.0 & 1.30 & & 2.40 & 12.20 & & & $33^{\circ} 15.12^{\prime}$ & $116^{\circ} 03.99^{\prime}$ & 8 \\
\hline & 1604 & 3.9 & 31.90 & 41.40 & 33.50 & 43.40 & & & $33^{\circ} 16.34^{\prime}$ & $116^{\circ} 03.50^{\prime}$ & 8 \\
\hline \multirow[t]{2}{*}{$54-03-20$} & 0419 & 4.9 & 30.80 & & 32.10 & 41.90 & & & $33^{\circ} 15.66^{\prime}$ & $116^{\circ} 04.71^{\prime}$ & 8 \\
\hline & 0604 & 4.3 & 4.70 & & 6.30 & 16.10 & & & $33^{\circ} 16.44^{\prime}$ & $116^{\circ} 05.81^{\prime}$ & 8 \\
\hline \multirow[t]{2}{*}{$54-03-23$} & 0414 & 5.1 & 1.60 & & 3.30 & 12.90 & & & $33^{\circ} 16.31^{\prime}$ & $116^{\circ} 07.30^{\prime}$ & 8 \\
\hline & 0423 & 3.9 & 41.50 & & 43.90 & 53.70 & & & $33^{\circ} 18.38^{\prime}$ & $116^{\circ} 08.84^{\prime}$ & 8 \\
\hline 54-04-04 & 0429 & 4.1 & 31.40 & 41.10 & 32.70 & 42.60 & & & $33^{\circ} 15.53^{\prime}$ & $116^{\circ} 02.52^{\prime}$ & 8 \\
\hline
\end{tabular}

A station delay of $-0.16 \mathrm{sec}$ for the $\mathrm{BBC} P$ wave was determined from three recent earthquakes in the 1954 area recorded at station BTL (Figure 1). A station delay of $-0.20 \mathrm{sec}$ was used for the $P_{g}$ arrival at RVR from the 1954 main shock. The $P$-wave station delay for area 8 listed in Table 1 is for the $P_{n}$ arrival which is the first arrival for most of the aftershocks.

The aftershock (rupture) zone of the 1954 earthquake occurred in an area where no surface expression of strike-slip faulting is mapped. Instead, folded late Tertiary and Quaternary sediments are seen (Bartholomew, 1970; Sharp, 1975, 1981).

Relocated $M_{L} \geqq 2.5$ seismicity in the region of the 1954 earthquake for the $6 \mathrm{yr}$ preceding the main shock is shown in Figure 9a. Although some seismicity occurred in the area of the eventual aftershock zone, small earthquakes are noticeably absent from the main shock epicentral area. Ten weeks before the main shock, a burst of five earthquakes $\left(M_{L} 3.0\right.$ to 4.2$)$ occurred during an 8-hr period. These earthquakes occurred in the center of the future rupture zone between the main shock and the cluster of aftershocks (Figure 9b).

1942 Earthquake. The 21 October 1942 earthquake $\left(M_{L} 6.3\right)$ was determined by Richter (1958) to have an epicenter a few kilometers west of the junction of the Coyote Creek and Superstition Mountain faults. Taking into account the error 


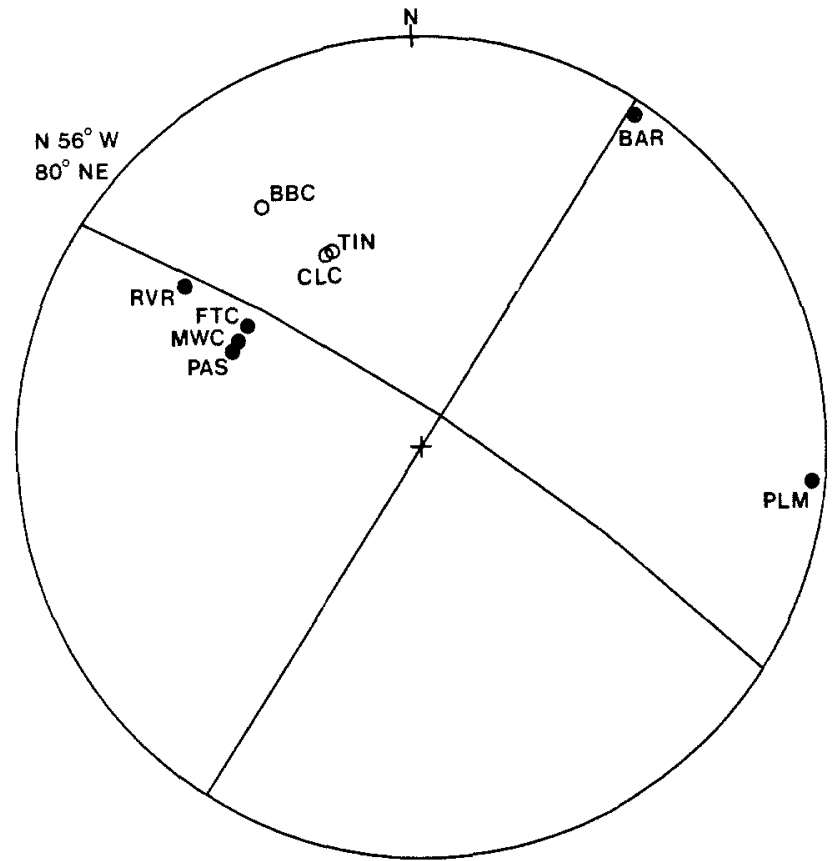

FIG. 8. $P$-wave first motion surce mechanism for the 1954 Salada Wash earthquake. Solid circles, compression; open circles, dilatation. Lower hemisphere, equal-angle projection. The southern California seismograph stations are Barrett Dam (BAR), Big Bear (BBC) China Lake (CLC), Fort Tejon (FTC), Mount Wilson (MWC), Pasadena (PAS), Palomar (PLM), Riverside (RVR), and Tinemaha (TIN). BAR and RVR are nodal.

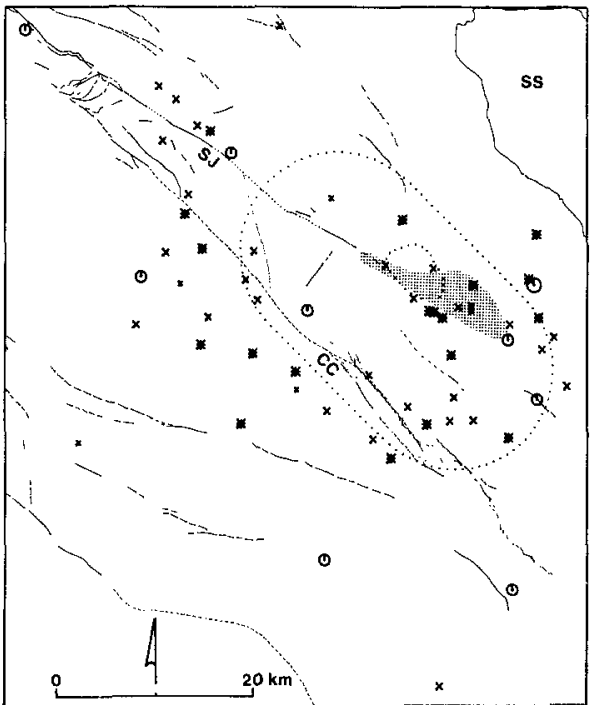

a

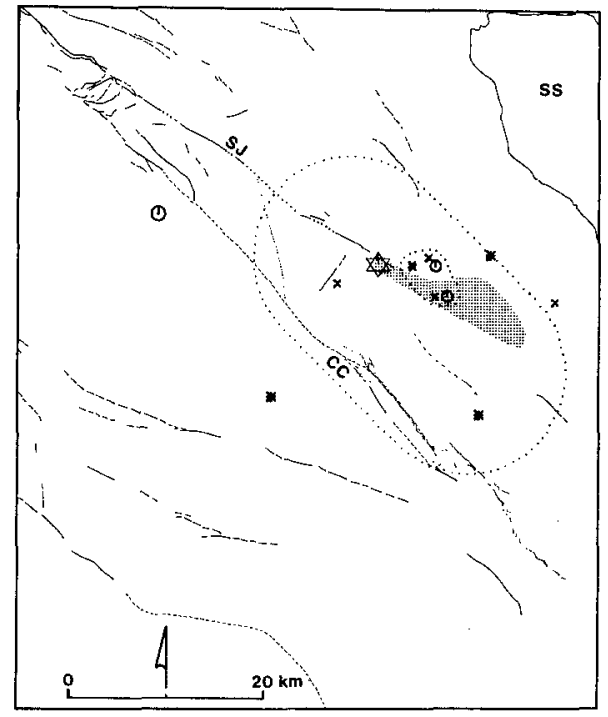

b

FIG. 9. (a) Relocated earthquakes $M_{L} \geqq 2.5$ in the area of the 1954 earthquake which occurred between 1 January 1948 and 3 January 1954. The earthquakes have catalog locations within the large area outlined by dots. The magnitude key is the same as in Figure 3 with the addition that small $\mathrm{x}=M_{L}$ 2.5. The 1954 main shock and aftershock zone is indicated by shading. (b) Relocated earthquakes which occurred between 4 January 1954 and 19 March 1954. The burst of earthquakes which occurred 4 January 1954 ten weeks before the 19 March 1954 main shock are contained within the small dotted outline. The 1954 main shock epicenter is plotted and the aftershock zone is indicated by shading. Note that this small burst of seismicity occurred in an area that was relatively nonseismic at the $M_{L} \geqq 2.5$ level for the preceding 6 yr. 
possible in that epicentral determination, previous researchers (e.g., Thatcher et al., 1975; Sanders and Kanamori, 1984) assumed that the 1942 earthquake was very likely situated on the northwest end of the Superstition Hills fault abutting the southeast end of the 1968 Borrego Mountain earthquake rupture. Such a location would fit nicely into a picture of large earthquake rupture on adjoining segments of the San Jacinto fault zone. Our analysis of the $P$ - and $S$-wave arrival time data from stations PLM, LJC, CUY, and RVR, however, indicates that the 1942 event is probably not located on the Superstition Mountain fault but rather is located near the Fish Creek Mountains southwest of the 1968 Borrego Mountain fault rupture.

For the 1942 main shock, the only arrival times available from nearby stations $(80$ to $160 \mathrm{~km}$ ) are $P$-wave times at stations PLM, LJC, and RVR. At these stations, no main shock $S$-wave times can be read since the seismograms are clipped after the first arrivals. Since the use of these three arrival times would result in a poorly constrained location, we have attempted to determine the range of possible $S-P$ times at PLM, LJC, and RVR from the seismograms of the early aftershocks. At station LJC, the $S-P$ times of five larger $\left(M_{L} \geqq 3.5\right)$ early aftershocks from 10 to 105 min after the main shock range from 12.8 to 13.6 sec. At station RVR, four aftershocks from $2 \frac{1}{2}$ to $8 \mathrm{~min}$ after the main shock have $S-P$ times ranging from 19.3 to $21.8 \mathrm{sec}$. The similar record from station PLM is missing from the Caltech seismogram library, so the $S$ - $P$ times of the early aftershocks recorded at this station cannot be determined by us. We calculated main shock epicenters using the delay values from area 9 (Figure 2, Table 6), the extreme LJC $S$ - $P$ times, and the smaller RVR $S-P$ time, and find that they fall within an area about $5 \mathrm{~km}$ in radius centered on the epicenter shown in Figure 3 and listed in Table 7. The larger RVR $S-P$ time gives very poor location error numbers and so is not used. A location determined using only the three $P$-wave times lies $15 \mathrm{~km}$ west of our preferred location. We feel that the epicentral location error for the 1942 main shock is about 10 to $15 \mathrm{~km}$.

Even with the location uncertainty, it appears that the 1942 earthquake was not caused by rupture of the Superstition Mountain fault. Rupture of the southeastern part of the Coyote Creek fault, though, may be considered a possibility. The surface displacement along this section of the Coyote Creek fault during the 1968 Borrego Mountain earthquake was only about 25 per cent of the maximum measured further northwest near the 1968 main shock epicenter, suggesting that this section of the fault may have slipped during an earlier event. However, eight of the best-located 1942 aftershocks ( $M_{L} 4.0$ to 4.5 , location error about $5 \mathrm{~km}$ ) are located within a 15 by $18 \mathrm{~km}$ area not associated with any one fault strand, and all have epicenters southwest of the Coyote Creek fault in an area of intensely faulted Pliocene sediments (Figure 3). This suggests that a main shock location on the Coyote Creek fault is unlikely, since large aftershocks would be expected to lie along the fault trace, as was observed for aftershocks of the 1968 Borrego Mountain earthquake. In addition, the dissimilarity of strong motion seismograms recorded at El Centro for the 1942 and 1968 earthquakes supports the idea that the two events were not produced by the same fault. The $P$-wave first motions provide some constraint on one of the source nodal planes; however, a unique solution cannot be obtained (Figure 10).

\section{Relative Sizes of the LaRge Earthquakes}

The local magnitudes determined by Richter for the 1937, 1942, 1954, and 1968 earthquakes are $6.0,6 \frac{1}{2}, 6.2$, and 6.4. Depending on the availability of on-scale 
RUPTURE PATTERNS/PRESHOCKS IN THE SAN JACINTO FAULT ZONE 1201

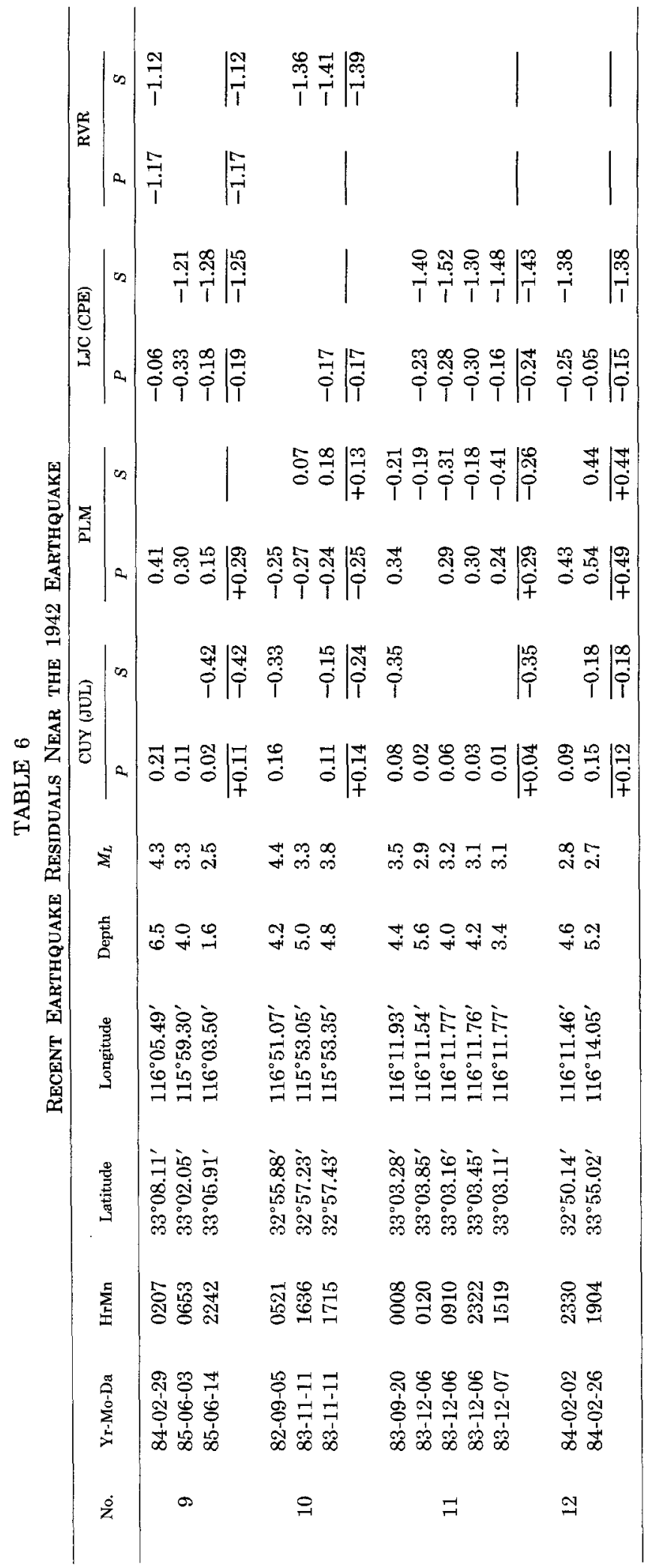


Wood-Anderson recordings, each of the $M_{L}$ values was determined by Richter in a slightly different manner.

Richter found the 1937 and 1954 local magnitudes by averaging the magnitudes at three of the southern California seismograph stations which recorded the maxi-

TABLE 7

Relocated 1942 Main Shock AND Some $M_{L} \geqq 4.0$ Aftershocks

\begin{tabular}{|c|c|c|c|c|c|c|c|c|c|c|c|c|c|}
\hline \multirow{2}{*}{ Yr-Mo-Da } & \multirow{2}{*}{ HrMn } & \multirow{2}{*}{$M_{L}$} & \multicolumn{2}{|c|}{ CUY } & \multicolumn{2}{|c|}{ PLM } & \multicolumn{2}{|c|}{ LJC } & \multicolumn{2}{|c|}{ RVR } & \multirow{2}{*}{ Latitude } & \multirow{2}{*}{ Longitude } & \multirow{2}{*}{ Depth } \\
\hline & & & $P$ & $S$ & $P$ & $s$ & $P$ & $S$ & $P$ & $S$ & & & \\
\hline \multirow[t]{7}{*}{$42-10-21$} & 1622 & 6.5 & & & 30.0 & & 34.43 & & 40.96 & & $33^{\circ} 02.93^{\prime}$ & $116^{\circ} 05.28^{\prime}$ & 7 \\
\hline & 1625 & 5.0 & & & & & & & 46.06 & 67.85 & & & \\
\hline & 1626 & 5.0 & & & & & 16.62 & & 23.72 & 43.06 & $32^{\circ} 58.64^{\prime}$ & $116^{\circ} 08.07^{\prime}$ & 10 \\
\hline & 1634 & 4.5 & & & & & 00.51 & 14.08 & & 28.55 & $32^{\circ} 55.53^{\prime}$ & $116^{\circ} 00.64^{\prime}$ & 10 \\
\hline & 1910 & 4.5 & & & & & 48.83 & 61.34 & 58.70 & 80.26 & $32^{\circ} 44.04^{\prime}$ & $116^{\circ} 07.90^{\prime}$ & 10 \\
\hline & 2149 & 4.5 & & & 45.6 & & 49.2 & 62.2 & & & $32^{\circ} 58.81^{\prime}$ & $116^{\circ} 03.94^{\prime}$ & 10 \\
\hline & 2250 & 4.0 & & & 49.0 & & 52.3 & 64.5 & & & $32^{\circ} 57.62^{\prime}$ & $116^{\circ} 08.22^{\prime}$ & 10 \\
\hline \multirow[t]{3}{*}{$42-10-22$} & 1139 & 4.0 & 02.7 & 09.5 & & & 12.1 & 26.2 & 18.7 & 40.2 & $32^{\circ} 56.60^{\prime}$ & $115^{\circ} 58.24^{\prime}$ & 9 \\
\hline & 1255 & 4.0 & 05.2 & 13.1 & & & 15.0 & 30.1 & 19.8 & 41.2 & $33^{\circ} 04.03^{\prime}$ & $115^{\circ} 53.40^{\prime}$ & 6 \\
\hline & 1813 & 5.0 & & & & & 46.8 & 60.8 & 53.2 & 74.9 & $32^{\circ} 55.89^{\prime}$ & $115^{\circ} 57.16^{\prime}$ & 10 \\
\hline $42-10-25$ & 1859 & 4.0 & & & 53.8 & & 57.5 & 70.0 & 64.8 & & $32^{\circ} 59.07^{\prime}$ & $116^{\circ} 07.45^{\prime}$ & 7 \\
\hline $42-10-26$ & 0434 & 4.0 & & & 21.8 & & 24.2 & 36.0 & & 53.2 & $32^{\circ} 53.16^{\prime}$ & $116^{\circ} 10.12^{\prime}$ & 10 \\
\hline
\end{tabular}

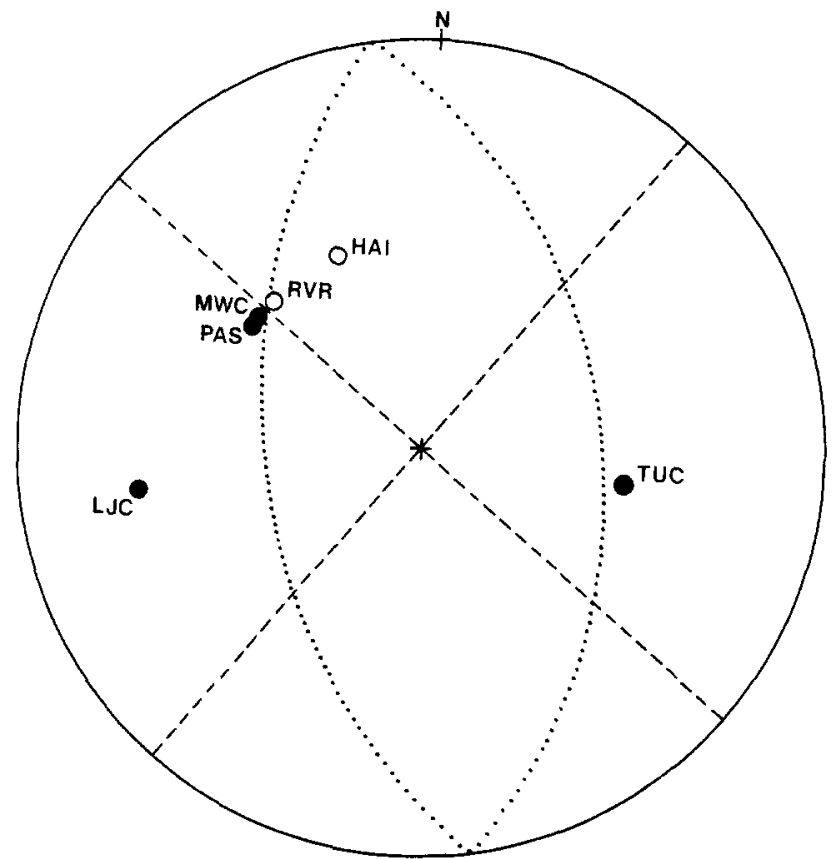

FIG. 10. $P$-wave first motions for the 1942 main shock. The dashed and dotted lines indicate the different mechanisms permissible by the data. Closed circles, compression; open circles, dilatation. Lower hemisphere, equal-angle projection. The southern California seismograph stations are the same as in Figure 5. TUC $=$ Tucson.

mum $S$ wave on scale. For the 1954 earthquake, there are on-scale recordings at HAI, PAS, and TIN, and for the 1937 earthquake there are recordings at these same stations plus SBC (Table 8). To obtain the 1937 magnitude, Richter threw out the lowest value at PAS before averaging to obtain $M_{L} 6.0$. PAS is also the low value in the 1954 readings but was included in the calculations for the average $M_{L}$ 
RUPTURE PATTERNS/PRESHOCKS IN THE SAN JACINTO FAULT ZONE 1203

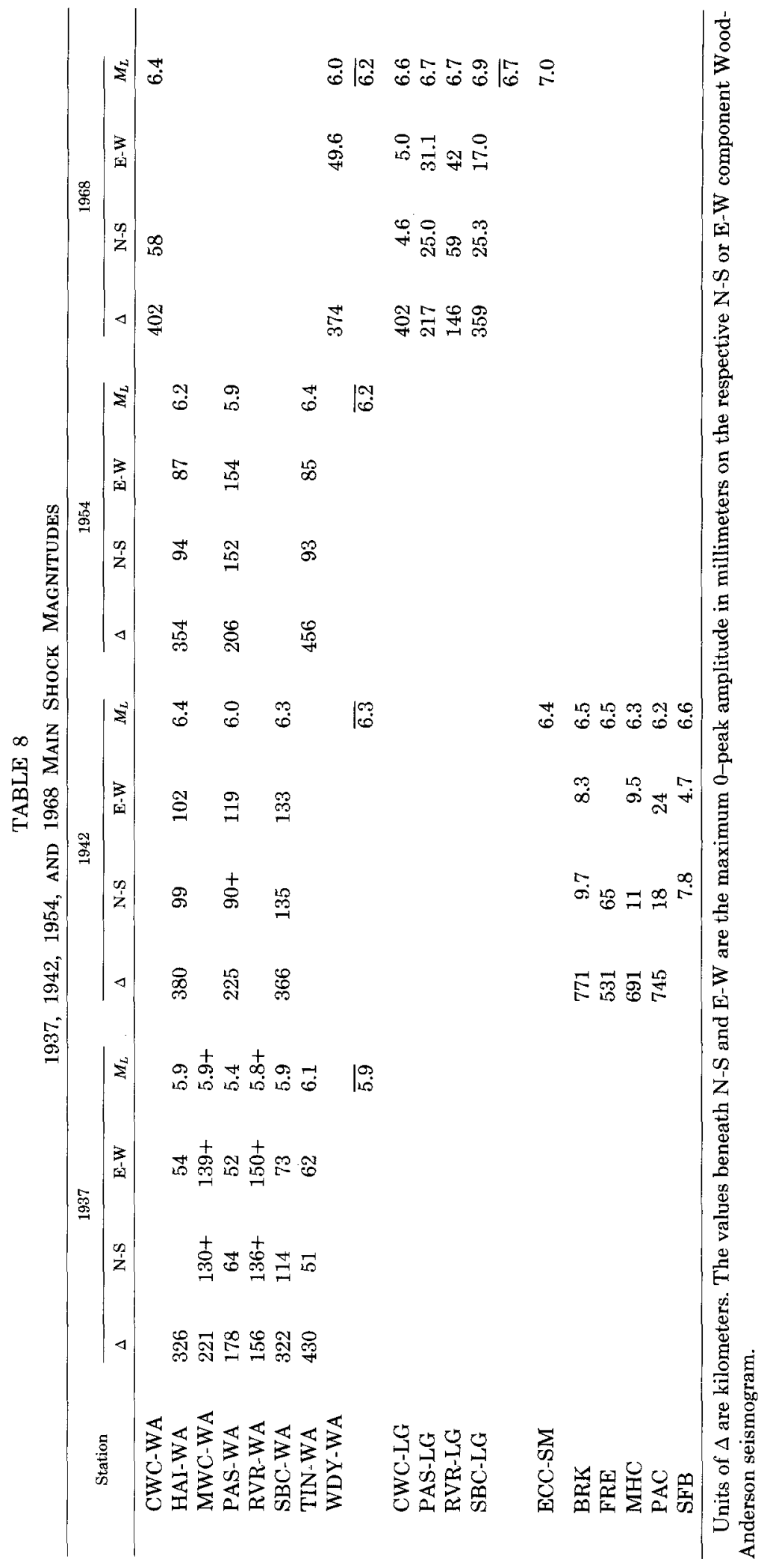


6.2. It seems that his use of the PAS data is arbitrary and that for consistency the PAS amplitude data should be given the same consideration. Whether the PAS data is used or not, the 1954 earthquake is, by comparison of individual stations, 0.3 to $0.5 M_{L}$ units larger than the 1937 earthquake. The median local magnitudes of the 1937 and 1954 earthquakes are 5.9 and 6.2 , respectively.

The amplitude data for the 1942 main shock are shown in Table 7. Richter's approximate $M_{L} 6 \frac{1}{2}$ for the 1942 event seems to have resulted from his uncertainty in the readings at the nearly clipped southern California stations and the high $M_{L}$ values at the stations in the central California area (Berkeley, BRK; Fresno, FRE; Mount Hamilton, MHC; Palo Alto, PAC; San Francisco, SFB). Of course, the central California stations are well beyond the distance range originally intended by Richter for use in $M_{L}$ determinations, and he must have extrapolated his attenuation curve somehow in order to obtain the magnitudes. If we use only the southern California amplitude data, we determine a median $M_{L} 6.3$ for the 1942 main shock. Station by station comparison with the 1937 earthquake shows that the 1942 event was 0.4 to $0.6 M_{L}$ units larger. Stations HAI and PAS suggest that the 1942 earthquake may have a slightly greater $M_{L}$ than the 1954 earthquake.

The 1968 main shock was clipped on most of the southern California WoodAnderson seismograms, so Richter used an $M_{L} 5.2$ aftershock to calibrate several low-magnification torsion instruments which recorded both the aftershock and main shock on scale (Allen and Nordquist, 1972). From this calibration, he found an $M_{L} 6.4$ for the main shock. Four pairs of these $100 \times$ torsion seismometers were also used by Kanamori and Jennings (1978) to obtain an $M_{L} 6.7$ for the Borrego Mountain main shock. The $0.3 M_{L}$ unit discrepancy between the Richter and the Kanamori and Jennings values may not be significant due to measurement errors of the small amplitudes of the $M_{L} 5.2$ aftershock on the low-gain instruments and are also due to the uncertainty in the response of the $100 \times$ torsion instruments (they are supposed to be essentially the same as the regular Wood-Anderson instruments) and the true gain of the regular Wood-Anderson instruments. The preferred $M_{L}$ is 6.8 [the average of the $100 \times$ torsion and strong motion local magnitudes (Kanamori and Jennings, 1978)], since it is based on the largest number of data and, hopefully, errors are averaged out.

The strong-motion records at El Centro (ECC) can be used to compare the relative sizes of the 1942 and 1968 earthquakes. Kanamori and Jennings (1978) used these strong-motion records to synthesize the equivalent Wood-Anderson response and found local magnitudes of 6.4 and 7.0 for the 1942 and 1968 events at El Centro, indicating an $M_{L}$ difference of 0.6 units.

In conclusion, it appears that local magnitudes of $6.8,6.3,6.2$, and 5.9 reflect the short-period sizes of the 1968, 1942, 1954, and 1937 earthquakes, respectively.

\section{CONCLUSIONS}

The purpose of this work is to locate precisely the large 1937, 1942, and 1954 earthquakes in the southern San Jacinto fault zone. This is done so that we will understand better the spatial relationships between the large earthquakes in this area and also the patterns of preshock and aftershock activity. Our relocations reveal many new facts about the historical earthquakes in the southern San Jacinto fault zone. They are

1. The 1937 Buck Ridge earthquake has an epicenter between the surface traces of the San Jacinto and Buck Ridge faults. Aftershocks suggest a rupture length of about $7 \mathrm{~km}$, mostly to the northwest. 
2. The 1980 Whitewash earthquake occurred on the San Jacinto fault at the northwest end of the 1937 aftershock zone and broke another couple of kilometers further northwest into the edge of the Anza seismic gap.

3. A significant earthquake cluster occurred near the Cahuilla Valley $1 \frac{1}{2}$ yr before the 1937 event.

4. The 1954 Arroyo Salada earthquake epicenter is located at the southeast end of the Clark strand of the San Jacinto fault, and aftershocks suggest unilateral rupture to the southeast of about $15 \mathrm{~km}$. No evidence of major faulting is apparent in the surface rocks of this area; instead, folded young sediments are seen. The $P$-wave first motions indicate right-slip faulting on a subsurface extension of the San Jacinto fault.

5. A significant cluster of seismicity occurred in the center of the 1954 rupture zone 10 weeks before the main shock.

6. We locate the 1942 earthquake main shock near the Fish Creek Mountains area southwest of and parallel to the southern end of the Coyote Creek fault. This earthquake is probably not located on the Superstition Mountain nor Superstition Hills faults. Eight $M_{L} \geqq 4.0$ aftershocks are spread over a 15 by $18 \mathrm{~km}$ area and do not cluster on any one fault. Differences in the strongmotion seismograms at El Centro between the 1968 and 1942 earthquakes support the relative locations of the two events.

7. The relation of the 1942 earthquake to slip in the San Jacinto fault zone is unknown.

8. Segments of the southern San Jacinto fault zone that have not slipped in large earthquakes since at least the late 1890's include the 20-km-long Anza seismic gap, the 25-km segment of the San Jacinto fault between the 1937 and 1954 events, the $45-\mathrm{km}$-long Superstition Mountain fault, and the $40-\mathrm{km}-$ long Superstition Hills fault.

9. Large earthquakes may be expected to occur on structures not presently considered as major parts of the San Jacinto fault zone. The 1942 and 1954 earthquakes are examples of this.

\section{ACKNOWLEDGMENTS}

We appreciate a critical review by Jim Pechmann and comments by Tom Hanks, Tom Rockwell, and Kerry Sieh. This research was supported by U.S. Geological Survey Contract 14-08-0001-21981 and Grant 14-08-0001-G1170.

\section{REFERENCES}

Allen, C. R. and J. M. Nordquist (1972). Foreshock, main shock, and larger aftershocks of the Borrego Mountain earthquake, U.S. Geol. Surv. Profess. Paper 787, 16-23.

Bartholomew, M. J. (1970). San Jacinto fault zone in the northern Imperial Valley, California, Geol. Soc. Am. Bull. 81, 3161-3166.

Doser, D. I. and H. Kanamori (1986). Spatial and temporal variations in seismicity in the Imperial Valley (1902-1984), Bull. Seism. Soc. Am. 76, 421-438.

Gutenberg, B. (1943). Earthquakes and structure in southern California, Geol. Soc. Am. Bull. 54, 499526.

Hadley, D. and H. Kanamori (1977). Seismic structure of the Transverse Ranges, California, Geol. Soc. Am. Bull. 88, 1469-1478.

Hamilton, R. M. (1972). Aftershocks of the Borrego Mountain earthquake from April 12 to June 12, 1968, U.S. Geol. Surv. Profess. Paper 787, 31-54.

Hanks, T. C., J. A. Hileman, and W. Thatcher (1975). Seismic moments of the larger earthquakes of the southern California region, Geol. Soc. Am. Bull. 86, 1131-1139.

Hileman, J. A., C. R. Allen, and J. M. Nordquist (1973). Seismicity of the southern California region 1 
January 1932 to 31 December 1972, Seismological Laboratory, California Institute of Technology, Pasadena, California.

Johnson, C. E. (1979). CEDAR-An approach to the computer automation of short-period local seismic networks, Ph.D. Thesis, California Institute of Technology, Pasadena, California, 332 pp.

Kanamori, H. and D. Hadley (1975). Crustal structure and temporal velocity change in southern California, Pageoph 113, 257-280.

Kanamori, H. and P. C. Jennings (1978). Determination of local magnitude, $M_{L}$, from strong-motion accelerograms, Bull. Seism. Soc. Am. 68, 471-485.

Pechmann, J. C. (1983). The relationship of small earthquakes to strain accumulation along major faults in southern California, Ph.D. Thesis, California Institute of Technology, Pasadena, California, 175 pp.

Richter, C. F. (1958). Elementary Seismology, W. H. Freeman and Co., San Francisco, California, 768 pp.

Sanders, C. O. and H. Kanamori (1984). A seismotectonic analysis of the Anza seismic gap, San Jacinto fault zone, southern California, J. Geophys. Res. 89, 5873-5890.

Sharp, R. V. (1975). En echelon fault patterns of the San Jacinto fault zone, in San Andreas Fault in Southern California, vol. 118, J. C. Crowell, Editor, Special Report of the California Division of Mines and Geology, 147-154.

Sharp, R. V. (1981). Variable rates of Late Quaternary strike-slip on the San Jacinto fault zone, southern California, J. Geophys. Res. 86, 1754-1762.

Thatcher, W. and R. M. Hamilton (1973). Aftershocks and source characteristics of the 1969 Coyote Mountain earthquake, San Jacinto fault zone, California, Bull. Seism. Soc. Am. 63, 647-661.

Thatcher, W., J. A. Hileman, and T. C. Hanks (1975). Seismic slip distribution along the San Jacinto fault zone, southern California and its implications, Geol. Soc. Am. Bull. 86, 1140-1146.

Wood, H. O. (1937). The Terwilliger Valley earthquake of March 25, 1937, Bull. Seism. Soc. Am. 27, $305-312$.

SEISMOLOGICAL LABORATORY

CALIFORNIA INSTITUTE OF TECHNOLOGY

Pasadena, California 91125

Contribution No. 4305

Manuscript received 28 January 1986 